\title{
Cannabis, a Miracle Drug with Polyvalent Therapeutic Utility: Preclinical and Clinical-Based Evidence
}

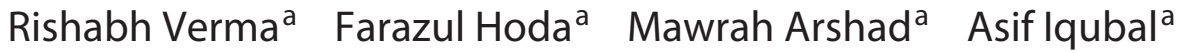 \\ Ali Nasir Siddiqui $^{\mathrm{b}}$ Mohammad Ahmed Khan ${ }^{\mathrm{a}}$ Syed Ehtaishamul Haque ${ }^{\mathrm{a}}$ \\ Mohd Akhtar ${ }^{\mathrm{a}}$ Abul Kalam Najmi ${ }^{\mathrm{a}}$ \\ aDepartment of Pharmacology, School of Pharmaceutical Education and Research, Jamia Hamdard, New Delhi, \\ India; ${ }^{b}$ Department of Pharmaceutical Medicine, School of Pharmaceutical Education and Research, Jamia Hamdard, \\ New Delhi, India
}

\section{Keywords}

Marijuana · Cannabis · Cannabidiol · Alzheimer .

Epilepsy · Cancer · Emesis · Chronic pain · Amyotrophic lateral sclerosis $\cdot$ Multiple sclerosis

\begin{abstract}
Cannabis sativa L. is an annual herbaceous dioecious plant which was first cultivated by agricultural human societies in Asia. Over the period of time, various parts of the plant like leaf, flower, and seed were used for recreational as well as therapeutic purposes. The main chemical components of Cannabis sativa are termed as cannabinoids, among them thekeypsychoactiveconstituentis $\Delta$-9-tetrahydrocannabinol and cannabidiol (CBD) as active nonpsychotic constituent. Upon doing extensive literature review, it was found that cannabis has been widely studied for a number of disorders. Very recently, a pure CBD formulation, named Epidiolex, got a green flag from both United States Food and Drug Administration and Drug Enforcement Administration for 2 rare types of epilepsies. This laid a milestone in medical cannabis research. This review intends to give a basic and extensive assessment, from past till present, of the ethnological, plant, chemical, pharmacological, and legal aspects of $C$. sativa.
\end{abstract}

karger@karger.com www.karger.com $/ \mathrm{mca}$

Karger"

GOPEN ACCESS
(C) 2021 The Author(s).

Published by S. Karger AG, Basel

This is an Open Access article licensed under the Creative Commons Attribution-NonCommercial-4.0 International License (CC BY-NC) (http://www.karger.com/Services/OpenAccessLicense), applicable to the online version of the article only. Usage and distribution for commercial purposes requires written permission.
Further, this review contemplates the evidence the studies obtained of cannabis components on Alzheimer's, Parkinson's, amyotrophic lateral sclerosis, multiple sclerosis, emesis, epilepsy, chronic pain, and cancer as a cytotoxic agent as well as a palliative therapy. The assessment in this study was done by reviewing in extensive details from studies on historical importance, ethnopharmacological aspects, and legal grounds of $C$. sativa from extensive literature available on the scientific databases, with a vision for elevating further pharmaceutical research to investigate its total potential as a therapeutic agent.

(c) 2021 The Author(s).

Published by S. Karger AG, Basel

\section{Introduction}

Cannabis, first traced back to Central Asia, is one of the most traditional psychotropic medications to humans. It is hard to establish as to when it was started to be used by the human population as it was used way before its first written evidence. Agreeing to archaeological revelations, it has been known in China at least since the Neolithic time frame, around 4,000 BC [1]. The most famous form of the cannabis plant is marijuana and hash- 


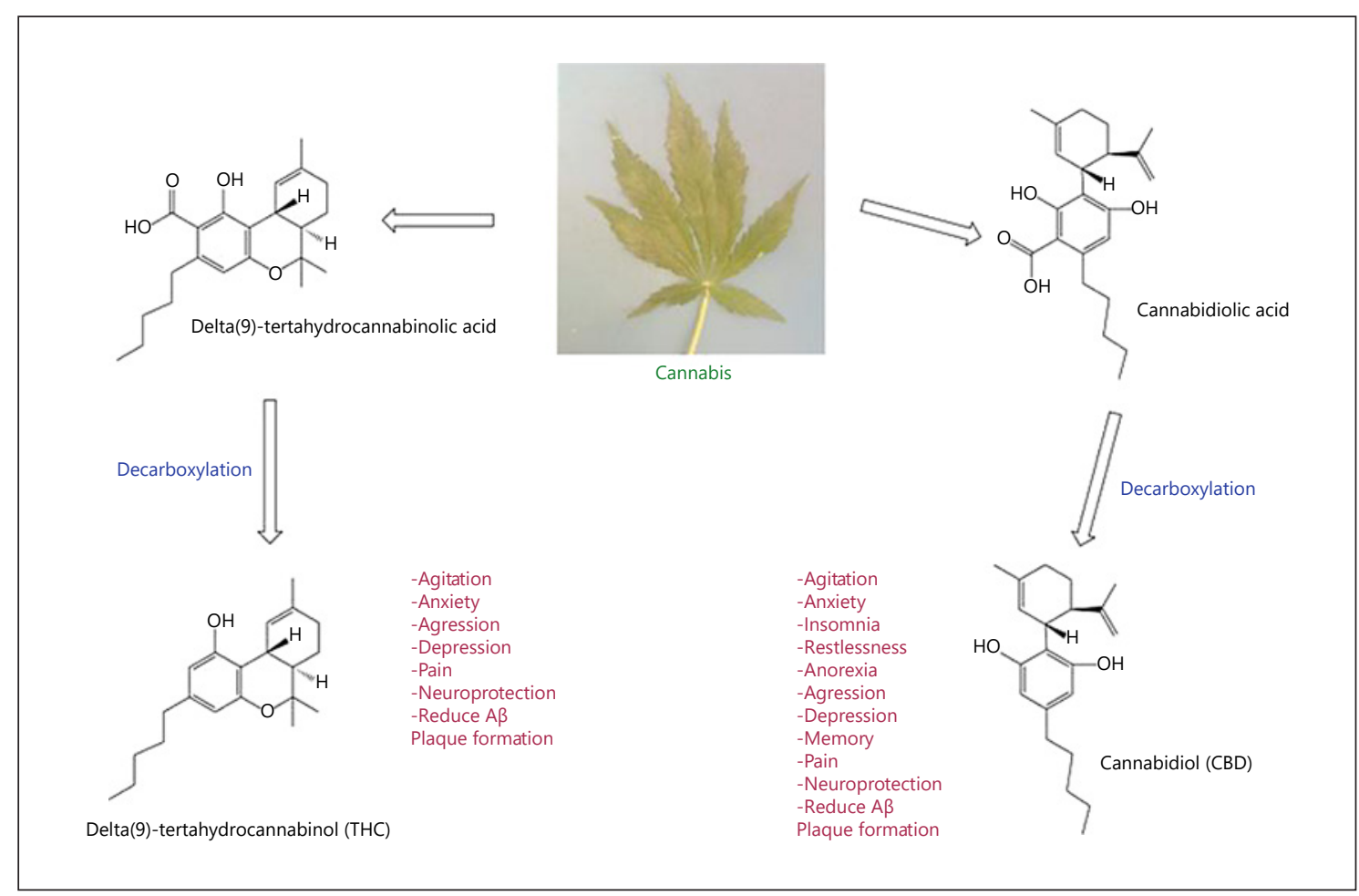

Fig. 1. Showing the different component of cannabis and its pharmacological effects. CBD, cannabidiol; THC, tetrahydrocannabinol; $A \beta$, amyloid $\beta$-peptide.

ish. Marijuana is a Mexican term at first ascribed to cheap tobacco but today referred to the dried leaves and flowers of the cannabis plant. Hashish, the Arabic name for Indian hemp, is the resin gum of the plant [2]. For hundreds of years, cannabis has been utilized as a source of fiber, food, oil and for religious, recreational, and therapeutic purposes [3]. It contains various mixtures of structurally active agents, for example, cannabinoids, terpenoids, flavonoids, and alkaloids [4]. The major psychoactive chemical of cannabis is delta-9-tetrahydrocannabinol (THC), commonly known as THC. Various other cannabinoids include delta-8-THC, cannabinol, cannabidiol (CBD), cannabicyclol, cannabichromene, and cannabigerol; however, they are available in little amounts and have no significant psychotropic activity as compared with THC, as shown in Figure 1 $[1,5]$. Presently, cannabinoids are used for symptomatic treatment, but there is evidence that states that they can be used to slow down the progression of neurodegenerative diseases [6]. Further, Cannabinoids, especially CBD, retard breast cancer cell proliferation [7], while THC retarded glioblastoma multiforme growth in animal. Models and a pilot clinical study showed that it depresses tumor cell proliferation in vitro
[8] and have evidence for other cancers like prostate, lung, and blood cancers. Other clinical conditions such as nausea, glaucoma, chronic pain, inflammation, multiple sclerosis, and epilepsy have shown relief or improvement from medical cannabis, as shown in Figure 1. Despite some contentious discussion on its medical use, unprescribed marijuana may lead to addiction. Its use during adolescence can affect mental development, and regular use could also lead to a high risk of anxiety and depression, especially in people with a genetic vulnerability [9].

Cannabis extracts contain several active compounds called cannabinoids. Among this, the most abundant ones are THC, its precursor CBD, and cannabinol. CBD lack psychoactive abilities but has other medical indications such as anticonvulsant effect and anticancer effects [10]. Cannabinoids are highly lipophilic compounds and were originally thought to simply diffuse through the cell membrane [11]. But in 1988, using saturable high-affinity binding of titrated cannabinoid in the homogenized brain of rat led to the discovery of cannabinoid receptors. They are now termed as $\mathrm{CB}$ receptors which were further classified into $\mathrm{CB} 1$ and $\mathrm{CB} 2$ [10]. CB1 was mainly identified in the central nervous system, while CB2 was subse- 
quently identified in the peripheral tissue [12]. Since the abundance of CB1 was found to be in CNS, it is known to have effects on motor coordination and short-term memory processing, while $\mathrm{CB} 2$ is primarily expressed in leukocytes and used as hematopoietic development [13]. Discovery of cannabinoid receptors led to a search of endogenous transmitters. In 1992, with radiolabeled extracts of pig brain was identified the first endogenous mediator, $\mathrm{N}$-arachidonoylethanolamide [14]. A few years later, the second endocannabinoid, 2-arachidonoyl glycerol, was identified, and recently, 3 endocannabinoids with selectivity to $\mathrm{CB} 1$ and $\mathrm{CB} 2$ were discovered. The well-established endocannabinoids are anandamide and 2 -arachidonoyl glycerol, which have numerous roles, including working as "retrograde" mediator passing data from postsynaptic to presynaptic neurons [10]. THC and CBD are the most abundant cannabinoids that are scientifically studied as of now [15]. A synthetic version of THC, Marinol (dronabinol), is available on prescription. A newer synthetic THC developed was Cesamet (nabilone) for nausea and vomiting [16].

Therefore, this review expects to fill in as an educational tool with appropriate evidences about the benefits that therapeutic cannabis can offer. This information is primarily relevant as very recently, in July 2018, a cannabis-based product for epilepsy has been approved by the United States Food and Drug Administration (US FDA). Here, we give an outline of the history of cannabis in traditional system of medicine, fundamental science behind cannabis and the endocannabinoids framework, its evidence as a therapeutic agent in Alzheimer's, epilepsy, chronic pain, and cancer studies and along with its molecular mechanism and legal aspects.

\section{Method for Search}

Further, to identify the therapeutic action of cannabis, we performed a literature search on databases such as PubMed and Google Scholar, and there were no restriction on the time period. The following search terms or keywords were used alone or in combination: "Cannabis," "cannabinoids," "Pharmacotherapeutics," "Cannabidiol," "Alzheimer," "Epilepsy," "Cancer," "Emesis," "Chronic pain," "Amyotrophic Lateral Sclerosis," and "multiple sclerosis." The literature search was restricted to studies published in English. Preprinted articles, clinical studies, preclinical studies, meta-analysis, systematic reviews, and narrative reviews are included, and those papers that are not having adequate information were excluded.

Cannabis, a Miracle Drug

\section{History}

A plant-based botanical, cannabis, has its first evidence in the ancient world. First evidence dates back to 5,000 years to present-day Romania [17]. Another evidence of THC, in ashes, around $400 \mathrm{AD}$, was found indicating toward a period of its medical use [18]. In and around 1,000 BC, a marijuana drink mixed with milk, Bhang, was used as an anesthetic and antiphlegmatic in India [19]. A Chinese medicinal text (1,578 AD) (Bencao Gangmu Materia Medica, by Li Shizhen) depicts the use of cannabis to treat emesis, parasitic contaminations, and hemorrhage [20]. The Jamestown pioneers brought the Marijuana plant, usually known as hemp, to North America in 1611, and all through the frontier time frame, hemp fiber was an important export [21]. The great British herbalist Nicholas Culpeper (1616-1654) wrote in his book The English Physician (sic) that marijuana extracts "allayed Inflammations in the Head ... facilitates the agonies of the Gout ... Knots in the Joints, (and) the torments of the Sinews and Hips." Culpeper's preparations most likely had little psychoactivity as local cannabis developed in northern latitudes has generally low THC content [22].

In the nineteenth and early twentieth century, in the US, cannabis was widely used as a patented medicine and appeared in US pharmacopeia in 1850. Marijuana tax act came into action in 1937 which imposed federal restriction on cannabis sale and use [17]. After this act, US pharmacopeia dropped cannabis in 1942 with legal penalties coming into existence in 1951 and 1956 [23, 24]. California, in 1996, became the first state to legalize cannabis under medical supervision under the Compassionate Use Act. As of now, 9 states have legalized recreational marijuana and 29 states legalized medical marijuana with other parts of world [25].

\section{Pharmacotherapeutics of Cannabis}

\section{Alzheimer's Disease and Cannabis}

According to WHO, Alzheimer's disease (AD) is portrayed by a dynamic decrease in psychological function. Promotion of AD is generously expanded among individuals matured 65 years or more, with a dynamic decrease in memory, thinking, language, and learning capacity. The promotion of AD ought to be separated from an ordinary age-related decrease in cognitive function, which is progressively slow and connected with less inability. Illness frequently begins with mild symptoms and 


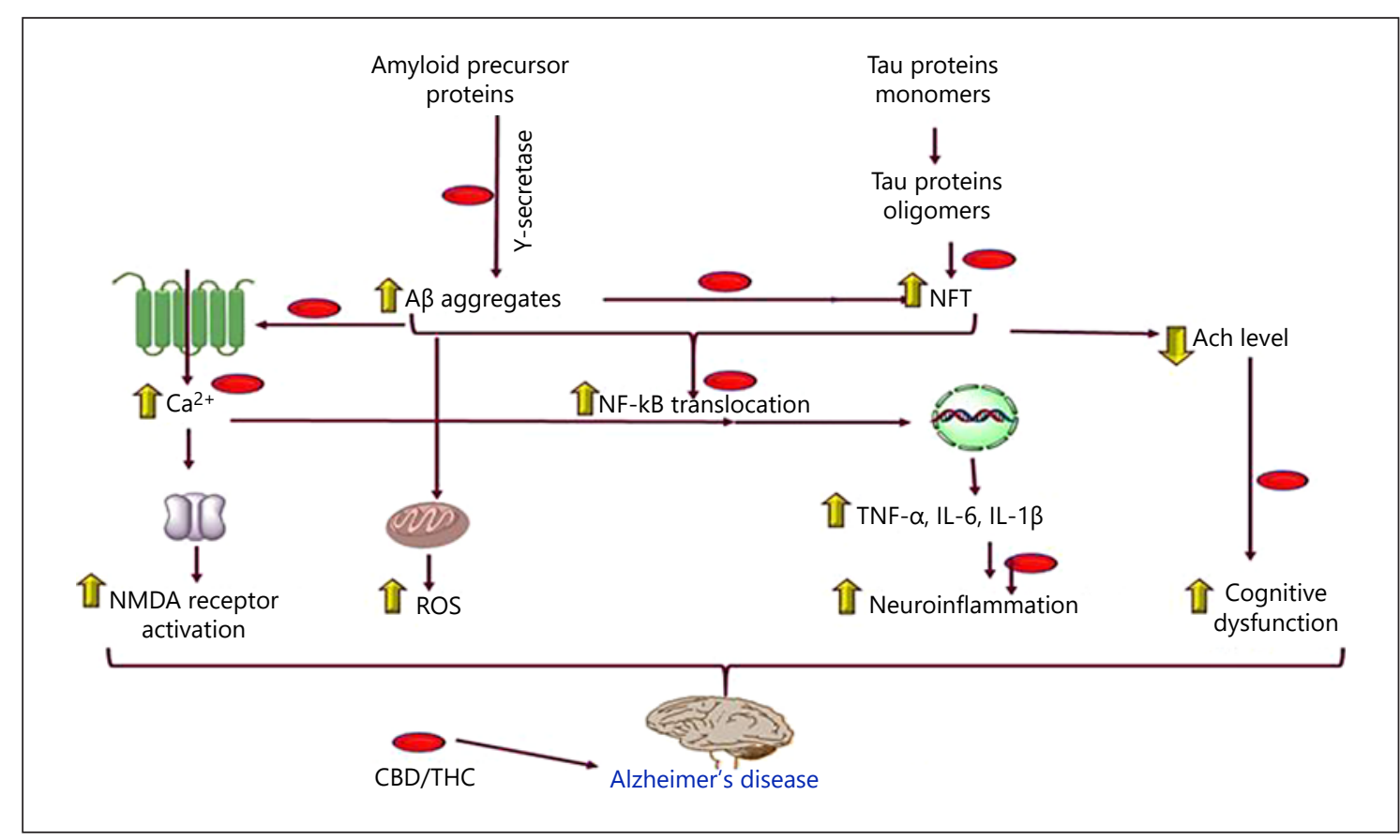

Fig. 2. Showing the therapeutic intervention of $\mathrm{CBD} / \mathrm{THC}$ in the pathogenesis of $\mathrm{AD}$. $\mathrm{CBD}$, cannabidiol; $\mathrm{THC}$, tetrahydrocannabinol; $\mathrm{AD}$, Alzheimer's disease; $\mathrm{A} \beta$, amyloid $\beta$-peptide.

finishes with serious brain damage [26]. According to Alzheimer's association, 1 in 10 people of age above 65 years have Alzheimer's dementia, as of 2019, and risk of it increases with age [27]. One of the main factors in Alzheimer's progression is the accumulation of beta-amyloid proteins in the patient. A randomized, double-blind clinical study at the University of Toronto suggested that nabilone, a synthetic cannabinoid, was effective in treating agitation and other behavioral symptoms of Alzheimer's [28]. Medical cannabis oil containing THC as an addon leads to a significant decrease in neurobehavioral symptoms such as delusions, agitation/aggression, irritability, apathy, sleep, and caregiver distress. Medical cannabis can help prevent or delay the onset of Alzheimer's and slow the disease's progression [29]. Furthermore, THC competitively represses the compound acetylcholinesterase and additionally prevents acetylcholinesterase-actuated amyloid $\beta$-peptide aggregation, the key neurotic marker of Alzheimer's disease. Compared to present medications recommended for the treatment of Alzheimer's disease, THC is an impressively predominant inhibitor of amyloid $\beta$-peptide aggregation [30]. Nighttime agitation has been one of the major symptoms of severe dementia and has become the main problem for caregivers. In an open-label pilot study, 6 patients with severe de- mentia were treated with dronabinol, a pure isomer of THC, for 2 weeks. This investigation recommends that dronabinol could lessen nighttime agitation and motor activity in extremely demented patients. Hence, it creates the impression that dronabinol might be a safe new treatment alternative for behavioral and circadian disturbances in dementia [31]. Dronabinol treatment diminished the seriousness of disturbed behavior. Adverse reactions were observed more with dronabinol treatment as compared with placebo; adverse reaction included euphoria, somnolence, and tiredness, but it did not require discontinuation of the therapy. These results demonstrated that dronabinol is a promising novel therapeutic agent that may be significant for the treatment of anorexia just as to improve disturbed behavior in patients with $\mathrm{AD}$ [32]. Cannabinoid receptor agonist anandamide and noladin ether inhibit amyloid-peptide, which is responsible for neurodegenerative changes during Alzheimer's. At very low concentration, nanomolar, anandamide, and noladin ether showed concentration-dependent inhibition of $\mathrm{A}$ peptide toxicity [33]. Behavioral disturbances in patients with dementia associated with Alzheimer's have a significant therapeutic effect using dronabinol and perhaps other cannabinoids, thus it deserves further investigation to make the life of severely demented patients a bit lively
Med Cannabis Cannabinoids 2021;4:43-60 DOI: $10.1159 / 000515042$
Verma/Hoda/Arshad/Iqubal/Siddiqui/ Khan/Haque/Akhtar/Najmi 
Table 1. Evidence of the use of cannabis in $\mathrm{AD}$ [28-41]

\begin{tabular}{|c|c|c|c|c|}
\hline Type of study & Objective & Result & Year & Ref. \\
\hline Clinical study & $\begin{array}{l}\text { Safety and efficacy of medical cannabis oil for behavioral and } \\
\text { psychological symptoms of dementia: an open-label, add-on, } \\
\text { pilot study }\end{array}$ & $\begin{array}{l}\text { Delusions, irritability, agitation, apathy, and sleep } \\
\text { disorders were significantly decreased }\end{array}$ & 2016 & {$[29]$} \\
\hline Clinical study & $\begin{array}{l}\text { Cannabinoids for the treatment of agitation and aggression in } \\
\mathrm{AD}\end{array}$ & $\begin{array}{l}\text { Nabilone improved agitation and other behavioral } \\
\text { symptoms in patients with } \mathrm{AD}\end{array}$ & 2015 & {$[28]$} \\
\hline Clinical study & $\begin{array}{l}\text { Dronabinol for the treatment of agitation and aggressive } \\
\text { behavior in acutely hospitalized severely demented patients } \\
\text { with noncognitive behavioral symptoms }\end{array}$ & $\begin{array}{l}\text { A treatment with oral THC significantly decreased } \\
\text { agitation as well as improvement in sleep duration } \\
\text { and appetite }\end{array}$ & 2014 & {$[34]$} \\
\hline Clinical study & $\begin{array}{l}\text { The cannabinoid receptor agonist nabilone for the treatment } \\
\text { of dementia-related agitation }\end{array}$ & $\begin{array}{l}\text { Dramatic reduction in the severity of agitation and } \\
\text { other behavioral symptoms }\end{array}$ & 2008 & {$[36]$} \\
\hline Clinical study & Delta-9-THC for nighttime agitation in severe dementia & $\begin{array}{l}\text { Reduction in nighttime agitation in severe } \\
\text { dementia }\end{array}$ & 2006 & {$[31]$} \\
\hline Clinical study & $\begin{array}{l}\text { A tale of } 2 \text { cannabinoids: the therapeutic rationale for } \\
\text { combining THC and CBD }\end{array}$ & $\begin{array}{l}\text { Significant reduction in agitation with the use of } \\
\text { THC }\end{array}$ & 2006 & {$[38]$} \\
\hline Clinical study & $\begin{array}{l}\text { Effects of dronabinol on anorexia and disturbed behavior in } \\
\text { patients with } \mathrm{AD}\end{array}$ & $\begin{array}{l}\text { Higher weight gain and reduction in disturbed } \\
\text { behavior with THC }\end{array}$ & 1997 & {$[32]$} \\
\hline Preclinical study & $\begin{array}{l}\text { Efficacy of cannabinoids in a preclinical drug-screening } \\
\text { platform for } \mathrm{AD}\end{array}$ & $\begin{array}{l}\text { THC and CBD combination led to synergistic } \\
\text { neuroprotection }\end{array}$ & 2019 & {$[39]$} \\
\hline Preclinical study & $\begin{array}{l}\text { The marijuana component CBD inhibits } \beta \text {-amyloid-induced } \\
\text { tau protein hyperphosphorylation through } \mathrm{Wnt} / \beta \text {-catenin } \\
\text { pathway rescue in PC12 cells }\end{array}$ & $\begin{array}{l}\text { CBD inhibits hyperphosphorylation of tau protein } \\
\text { in } \mathrm{A} \beta \text {-stimulated PC12 neural cells, important } \\
\text { hallmark in } \mathrm{AD} \text {, suggestion is possible } \\
\text { pharmacological management in } \mathrm{AD}\end{array}$ & 2006 & {$[40]$} \\
\hline Preclinical study & $\begin{array}{l}\text { Anandamide and noladin ether prevent neurotoxicity of the } \\
\text { human } A \beta\end{array}$ & $\begin{array}{l}\text { Anandamide and noladin ether, at nanomolar } \\
\text { concentrations, showed concentration-dependent } \\
\text { inhibition of } A \beta \text { toxicity }\end{array}$ & 2002 & {$[33]$} \\
\hline
\end{tabular}

$\mathrm{A} \beta$, amyloid $\beta$-peptide; AD, Alzheimer's disease; THC, tetrahydrocannabinol; CBD, cannabidiol.

and aid the caretakers as well [34]. Proposed molecular mechanism of $\mathrm{CBD}$ in $\mathrm{AD}$ is shown in Figure 2, and detailed preclinical and clinical study is shown in Table 1.

\section{Parkinson's Disease and Cannabis}

Parkinson's disease (PD) is the second most common neurodegenerative disease, the number of which is significantly increasing. Since 1990 (over 26 years), the number of individuals with PD doubled to over 6 million globally, and it is found that it affects men more than women [42]. PD is identified by the presence of TNF- $\alpha$, ILs, and other inflammatory mediators in the cerebrospinal fluids as well as in substantia nigra pars compacta of PD patients. Presence of the inflammatory mediators may chronically increase reactive oxygen species, playing a role in the progression of disease [43]. A study showed the neuroprotective effect of CBD in animal model, where administration of CBD for 2 weeks protected medical 
forebrain bundle from 6-hydroxydopamine toxicity [44]. Further, CBD protective effect against striatal atrophy caused by 3-nitropropionic acid, in vivo, confirmed its therapeutic effect [45]. An open-labeled pilot study on 6 outpatients of PD also received a flexible dose of CBD $(150 \mathrm{mg} /$ day) regimen for 4 weeks with usual therapy. There was a significant decrease in total score of scale used to follow-up PD patients and a decrease in psychotic symptoms, suggesting therapeutic benefits of CBD in PD patients [46].

\section{Amyotrophic Lateral Sclerosis, Multiple Sclerosis, and Cannabis}

Amyotrophic lateral sclerosis (ALS) is a neurodegenerative disease where motor neuron of brain and spinal cord are selectively degenerated, leading to muscle wasting and atrophy and further paralysis and death. Presence of cytokines and immune cell, including T cells, activated microglia, and astrocytes in degenerated motor neurons of ALS patients and mouse models became a biomarker for the progression of the disease [43]. ALS is found to develop with a uniform frequency in major western countries. Various epidemiological studies report that it is prevalent in 4.1-8.4 individuals in 100,000 people [47]. A study showed the involvement of $\mathrm{CB}$ receptors (specifically CB2) in transgenic animal model for ASL, and efficacy of CB2 agonist AM-1241 demonstrated an increase of $56 \%$ of survival interval, concluding that it may slow motor neurodegeneration, opening a new therapeutic domain for ASL [48]. Multiple sclerosis (MS) is an autoimmune chronic condition where immune system attacks axonal myelin sheaths of the neuron. MS affects 2.2 million people worldwide, as for 2016. Prevalence of it has substantially increased since 1990 though it is not common but a potentially severe cause of neurological disability [49]. Injury can occur anywhere in the brain or spinal cord so the symptoms are usually diverse. Axonal damage is followed by inflammation and neurodegeneration. At present, drugs targeting immune system are used to treat MS, but they have moderate and not satisfactory effects [43]. THC, $\Delta^{8}$-THC (a stable, less psychoactive analog of THC), and dexanabinol showed beneficial effects by reducing severity and incidence of neurological deficits in rats with experimental autoimmune encephalomyelitis [50]. A multicentered clinical trial with $660 \mathrm{MS}$ patients checked the efficacy of cannabis extracts and its synthetic products for its therapeutic effects. Fifteen weeks of treatment led to a mixed result where some treatment groups showed improvement in pain, spasticity, mobility, and sleep quality while in others no benefits was found [51].
These results suggest the therapeutic spectrum of cannabis in treatment of MS, and further large-scale studies can be done to confirm its effects.

\section{Epilepsy and Cannabis}

Epilepsy is a chronic noncommunicable disease of brain that affects people of all ages. Almost 50 million people, worldwide, suffers from this. According to WHO, the estimated proportion of people suffering from epilepsy globally is 29-30 per 100,000 [52]. The International League Against Epilepsy characterizes epilepsy as a sickness of the brain, conclusion of which requires (a) somewhere around 2 unprovoked seizures happening $>24$ h separated, (b) one unprovoked seizure and a likelihood for further seizures of at any rate $60 \%$, happening throughout the following 10 years, or (c) the diagnosis of an epilepsy disorder [53]. Although enthusiasm for "medical cannabis" and its constituents for the treatment of seizures endured as the years progressed, it is just in the most recent decade that preclinical and clinical investigation into the potential use of cannabis in the treatment of epilepsy has exploded [54]. A case report of 1975 showing a 24-year-old man taking therapeutic doses of phenobarbital and diphenylhydantoin, smoked cannabis as an additional therapy. A phase 2 study of 15 patients suffering from secondary generalized epilepsy was divided into 2 groups randomly. One group received 200-300 mg CBD daily while others received a placebo. The study was done for almost 4 months. Four out of 8 subjects from the treatment group showed no signs of convulsions over the period, while 3 other patients showed some improvement while only one of them remains ineffective. This indicated the potential use of CBD for epilepsy [55]. A 12-week open-label interventional trial including about 162 patients for analyzing the efficacy of CBD for treatmentresistant epilepsy. The findings of the studies indicated that treatment reduced the episodes of epilepsy with an adequate safety profile in both children and adults [56]. A retrospective cohort study with 74 patients with intractable epilepsy resistant to $>7$ antiepileptic drugs. A cannabis oil formulation of CBD:THC (20:1) was given as treatment. A significant therapeutic effect on the seizure load was observed. About $89 \%$ of children have reduced seizure frequency. In addition to this, an improvement in the behavior of the patient is also observed. Somnolence, fatigue, gastrointestinal disturbances, and irritability were observed as adverse effects [57]. Eighteen patients suffering from tuberous sclerosis complex, a genetic disorder that has a common manifestation of seizure, were treated with CBD $5-50 \mathrm{mg} / \mathrm{kg} /$ day for a period of 3
Verma/Hoda/Arshad/Iqubal/Siddiqui/ Khan/Haque/Akhtar/Najmi 
Fig. 3. Showing the therapeutic intervention of $\mathrm{CBD} / \mathrm{THC}$ in the pathogenesis of seizure. CBD, cannabidiol; THC, tetrahydrocannabinol.

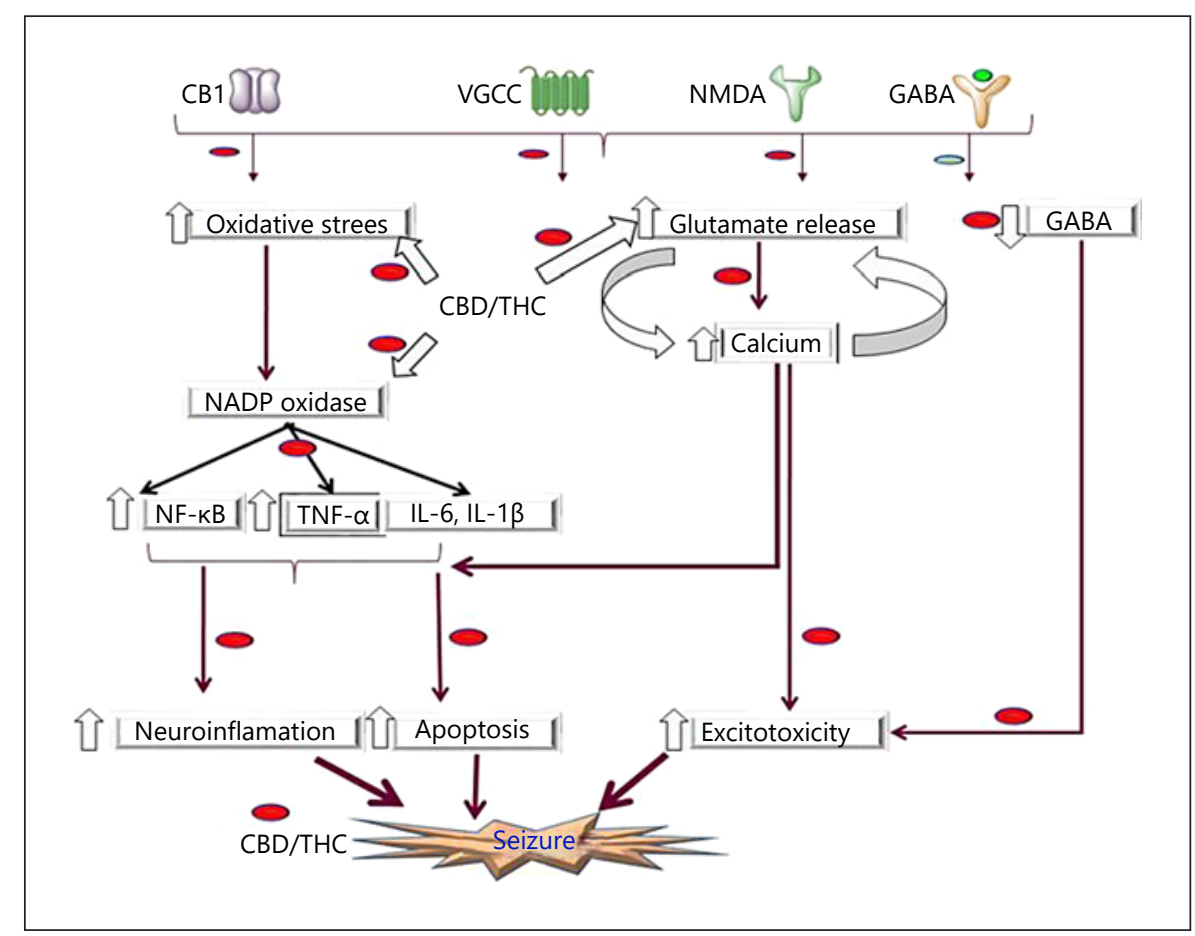

months. Initially, the median weekly seizure frequency was 22.0. By the end of 3 months, it got down to 13.3. These findings suggest that CBD can be effective and well tolerated for tuberous sclerosis complex seizure, but more investigation is necessary. A large prospective open-label study with 72 children and 60 adults with treatment-resistant epilepsy were treated with CBD up to $50 \mathrm{mg} / \mathrm{kg} /$ day for 48 weeks. Result of the study was observed as a significant improvement in the seizures at the 12th week that was maintained for the weeks ahead [58]. An observational longitudinal study was performed to evaluate the efficacy of cannabis oil with CBD:THC 20:1 on 57 patients of younger side (1-20 years) for 3 months. About $56 \%$ of the patients have a reduction in frequency of seizures of $>50 \%$ [59]. Nevertheless, there are growing evidence for the antiepileptic effect of cannabis and in line with it, molecular mechanism has been proposed. Considering the preclinical finding of $\mathrm{CBD}$, it has been reported that $\mathrm{CBD}$ exerts significant neuroprotection in drug-resistant epilepsy. CBD has been found to reduce neuronal excitability. Molecular mechanism proposed for the antiepileptic effect of CBD includes activation of TRPV2 channel, blockage of Kv2.1 channel, activation of adenosine and PPAR- $\gamma$ receptor. Additionally, CBD has been found to antagonize the activity of NMDA receptor by interacting with sigma 1 subunit if NMDA receptor.
Apart from its direct effect on seizure etiology, CBD also reduces the influx of calcium and production of reactive oxygen species; downregulates the activity of TNF-alpha, IL-6, IL-1ibeta, cox-2, and HMBG-1; and thus acts as potent antioxidant and anti-inflammatory molecule. Therefore, ample amount of experimental evidence supports the novel molecular mechanism of action of CBD to be a future therapeutic in seizure as shown in Figure 3, and detailed preclinical and clinical study is shown in Table 2 .

\section{Emesis and Cannabis}

Emesis (vomiting) is a complex phenomenon that involves the central as well as the peripheral nervous system. A number of factors induce emesis, but chemotherapy-induced emesis always remains a major concern for healthcare professionals. However, the central role of the central nervous system is more profound, and it involves dorsal vagal complex (DVC) that comprises area postrema, motor neuron of vagal nerves, and nucleus tractus solitarius. Chemoreceptor trigger zone present in the area postrema allows the chemotactic and other emetic-promoting substances to cross BBB and stimulate the different sections of the DVC [69]. DVC contains various receptors such as D1, D2, 5-HT3, NK1, CB1, and CB2, and these receptors are involved significantly in the induction of emesis [70, 71]. Not only CNS but PNS also plays a major role in the etiol- 
Table 2. Evidences of use of cannabis in epilepsy [53, 55-57, 59-68]

\begin{tabular}{|c|c|c|c|c|}
\hline Type of study & Objective & Result & Year & Ref. \\
\hline Clinical study & $\begin{array}{l}\text { Efficacy and tolerability of add-on CBD in pediatric patients } \\
\text { with drug-resistant epilepsy: an open exploratory } \\
\text { interventional study in México }\end{array}$ & $\begin{array}{l}\text { Treatment of CBD oil in drug-resistant epilepsy in } \\
\text { children and adults is showing good efficacy and } \\
\text { tolerability }\end{array}$ & 2019 & {$[60]$} \\
\hline Clinical study & $\begin{array}{l}\text { Marijuana use among patients with epilepsy at a tertiary care } \\
\text { center }\end{array}$ & $\begin{array}{l}\text { High CBD content formulation of medical marijuana } \\
\text { was reported to have better epilepsy control as } \\
\text { compared with high THC formulation }\end{array}$ & 2019 & {$[61]$} \\
\hline Clinical study & $\begin{array}{l}\text { CBD improves frequency and severity of seizures and } \\
\text { reduces adverse events in an open-label add-on prospective } \\
\text { study }\end{array}$ & $\begin{array}{l}\text { CBD reduces seizures in several childhood-onset } \\
\text { epilepsy }\end{array}$ & 2018 & {$[53]$} \\
\hline Clinical study & $\begin{array}{l}\text { CBD for treatment of refractory childhood epilepsies: } \\
\text { experience from a single tertiary epilepsy center in Slovenia }\end{array}$ & $\begin{array}{l}\text { About } 50 \% \text { of the children with epilepsy in the study } \\
\text { show significant improvement following CBD } \\
\text { treatment }\end{array}$ & 2018 & {$[62]$} \\
\hline Clinical study & $\begin{array}{l}\text { Open-label use of highly purified CBD }\left(\text { Epidiolex }^{\circledR}\right) \text { in } \\
\text { patients with CDKL5 deficiency disorder and Aicardi, } \\
\text { Dup15q, and Doose syndromes }\end{array}$ & $\begin{array}{l}\text { CBD is effective in treatment-resistant epilepsy with } \\
\text { CDKL5 deficiency disorder and Aicardi, Dup15q, and } \\
\text { Doose syndromes }\end{array}$ & 2018 & {$[63]$} \\
\hline Clinical study & $\begin{array}{l}\text { Efficacy of CBD-enriched medical cannabis for treatment of } \\
\text { refractory epilepsy in children and adolescents: an } \\
\text { observational, longitudinal study }\end{array}$ & $\begin{array}{l}\text { A cannabis extract with } \mathrm{CBD} \text { and } \mathrm{THC} \text { reduced } \\
\text { seizures in epilepsy patients }\end{array}$ & 2018 & [59] \\
\hline Clinical study & $\begin{array}{l}\text { CBD for treating drug-resistant epilepsy in children: the } \\
\text { New South Wales experience }\end{array}$ & $\begin{array}{l}\text { Large study with CBD in patients with epilepsy } \\
\text { showed good long-term safety of the medicine }\end{array}$ & 2018 & {$[64]$} \\
\hline Clinical study & $\begin{array}{l}\text { CBD as a new treatment for drug-resistant epilepsy in } \\
\text { tuberous sclerosis complex }\end{array}$ & $\begin{array}{l}\text { CBD is effective in epilepsy due to tuberous sclerosis } \\
\text { complex }\end{array}$ & 2016 & {$[65]$} \\
\hline Clinical study & $\begin{array}{l}\text { CBD-enriched medical cannabis for intractable pediatric } \\
\text { epilepsy: the current Israeli experience }\end{array}$ & $\begin{array}{l}\text { Improvement in behavior and alertness, } \\
\text { communication, motor skills, and sleep of patients } \\
\text { with epilepsy }\end{array}$ & 2016 & {$[57]$} \\
\hline Clinical study & $\begin{array}{l}\text { CBD in patients with treatment-resistant epilepsy: } \\
\text { an open-label interventional trial }\end{array}$ & $\begin{array}{l}\text { CBD reduces seizure frequency in children as well as } \\
\text { adults }\end{array}$ & 2016 & {$[56]$} \\
\hline Clinical study & On the application of cannabis in pediatrics and epileptology & $\begin{array}{l}\text { Positive effects of THC in children with severe } \\
\text { neurological disorders }\end{array}$ & 2004 & {$[66]$} \\
\hline Clinical study & $\begin{array}{l}\text { Chronic administration of } \mathrm{CBD} \text { to healthy volunteers and } \\
\text { epileptic patients }\end{array}$ & $\begin{array}{l}50 \% \text { of the subjects remain free from convulsion crisis } \\
\text { while } 40 \% \text { showed partial improvement }\end{array}$ & 1980 & {$[55]$} \\
\hline Case report & $\begin{array}{l}\text { The use of CBD for seizure management in patients with } \\
\text { brain tumor-related epilepsy }\end{array}$ & $\begin{array}{l}\text { CBD is effective in epilepsy in patients with brain } \\
\text { tumor }\end{array}$ & 2017 & {$[67]$} \\
\hline Case report & Anticonvulsant nature of marijuana smoking & $\begin{array}{l}\text { Cannabis was able to control seizures in conjunction } \\
\text { with phenobarbital and diphenylhydantoin }\end{array}$ & 1975 & {$[68]$} \\
\hline
\end{tabular}

THC, tetrahydrocannabinol; CBD, cannabidiol.

ogy of emesis. Enteric nervous system and vagal nerves along with the myenteric and minor plexi regulate the peristalsis movement of the gut mucosa [72]. Abnormal contraction directly promotes the etiology of emesis via $\mathrm{M}$ receptor, D receptor, and GABA receptor [73]. In the number of preclinical and clinical studies, it was found that THC and CBD exert antiemetic action via inhibition of various neurotransmitter from the aforementioned receptors [74]. Studies have shown that CBD stimulates $\mathrm{CB} 1$ and $5 \mathrm{HT}$ receptor and inhibits dopaminergic receptors as well as ac- tivities of Ach $[69,75,76]$. A system review comprising 30 trials showed the superior antiemetic action of CBD as compared with metoclopramide, chlorpromazine, haloperidol, and domperidone. Similarly, in another study, $>600$ malignant patients were recruited and the administration of $\mathrm{CBD} / \mathrm{THC}$ effectively minimized the emetic episode when used as adjuvant therapy $[77,78]$. In brief, CBD/THC is a potent antiemetic molecule and can be future therapeutic as first-line therapy in chemotherapy-induced emesis, as shown in Figure 4. 


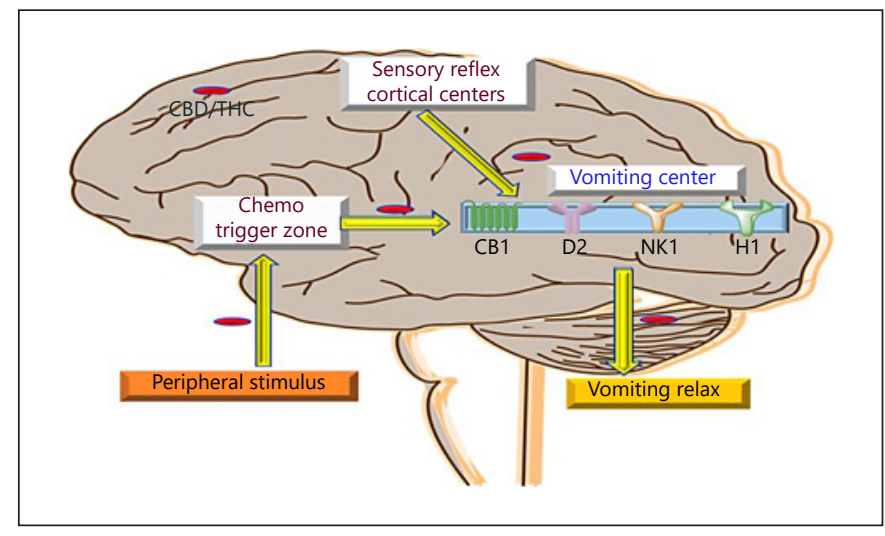

Fig. 4. Showing the therapeutic intervention of $\mathrm{CBD} / \mathrm{THC}$ in the pathogenesis of emesis. CBD, cannabidiol; THC, tetrahydrocannabinol.

\section{Cancer and Cannabis}

As of 2018, it is estimated that cancer has taken almost 9.6 million lives globally. This makes it the second leading cause of death. One in 6 deaths is due to cancer [79]. Treatment for cancer usually involving cancer chemotherapy is usually associated with adverse effects nausea, vomiting, pain, poor appetite, weight loss, and various other side effects. Cannabis administration either by inhaling or via oral route as oil or solid dosage has been found to be helpful in alleviating these adverse effects. The efficacy of medical cannabis in the treatment of cancer-related side effects has been investigated in many studies. A study of 1975 at the University of Iowa hospital, in which 10 patients with cancer were given varying doses of THC. This initial trial of THC on a limited number of patients revealed the analgesic effect of the drug [80]. A study with a large number of patients of 2,970 respondents out of which 1,248 followed up for 6 months showed a significant reduction in pain after 6 months. Initially on the pain scale (VAS scale), over $50 \%$ of patients had a pain intensity of $8-10$, while after 6 months of treatment $<5 \%$ of patients had such high levels of pain [81]. A 2-week, multicenter, double-blind, randomized, placebo-controlled, parallel-group study was conducted on a group of 177 patients with pain of 4 or above on the $0-10$ Numerical Rating Scale were treated with THC: CBD extract, THC, and placebo. Twice as many patients showed a reduction of $>30 \%$ from baseline pain Numerical Rating Scale score when compared to placebo [82]. At Vincent T Lombardi Cancer Research Center in 1988, 36 patients undergoing chemotherapy were studied for the efficacy of THC in reducing nausea and vomiting over prochlor-

Cannabis, a Miracle Drug perazine. THC showed a marked reduction in emesis and nausea in about $64 \%$ of the patients (23), while prochlorperazine was able to show the antiemetic effect in only 1 patient [83]; 8-THC is a cannabinoid which has lower psychotic activity than the conventional 9-THC; 8-THC was given as an adjuvant to children of age 3-13 years undergoing chemotherapy for 8 months, and vomiting was found to be completely prevented with negligible side effects [84].

Till now, we have discussed the use of cannabis and its extract as an adjuvant to cancer chemotherapy, but various preclinical studies showed that cancer had anticancer properties as well. Cannabinoids were found to act by modulating the signaling pathways, which in cancer cells is important for cell proliferation and survival [81]. When CBD was added in the growth media for growth of U87 and U373 human glioma cell lines, it drastically dropped mitochondrial oxidation mechanism and viability of glioma cells in a concentration-dependent manner [85]. In another study, CBD significantly decreased cell viability and further stated that activation of cannabinoid receptors led to prostate cancer cell apoptosis when done on AR-positive (LNCaP and 22RVI) and AR-negative (DU145 and PC-3) cell lines; cell viability and cell proliferation were checked using various techniques involving FACS, MTT assay, DNA fragmentation, etc [86]. THC when given with temozolomide (TMZ), the standard anticancer agent for glioblastoma multiforme, increased autophagy, and genetic inhibition of THC + TMZ-induced cell death was prevented. Further submaximal doses of $\mathrm{CBD}$ and THC remarkably reduced growth of glioma xenografts. TMZ + submaximal doses of CBD and THC produced antitumor effects in TMZ-sensitive and TMZresistant tumors, thus signifying the therapeutic effects of cannabinoids [87]. Tumor samples from THC-treated animals suggested that THC have an antiproliferative and antiangiogenic effect; this study also suggested that it may act by inhibiting the endothelial growth factor-induced phosphorylation of ERK1/2, JNK1/2, and AKT [88]. A study on MMTV-neu mice demonstrated the antitumor activity of THC and JWN-133, a CB2 selective agonist; it reduced breast tumor growth and number. Histological data revealed that it induced cancer cell apoptosis, inhibits its proliferation, and impaired tumor angiogenesis; this signifies that it could be used with conventional drugs for the treatment of ErbB-2-positive breast cancer [89]. Another study showed the effect of $\mathrm{CB} 2$ receptor agonist JWN-015 and THC on hepatocellular carcinoma (HCC) cell lines HepG2 and HuH-7. Cannabinoid-induced AMPK activation and autophagy led to reduced growth 
Fig. 5. Showing the therapeutic intervention of CBD/THC in the pathogenesis of cancer. CBD, cannabidiol; THC, tetrahydrocannabinol.

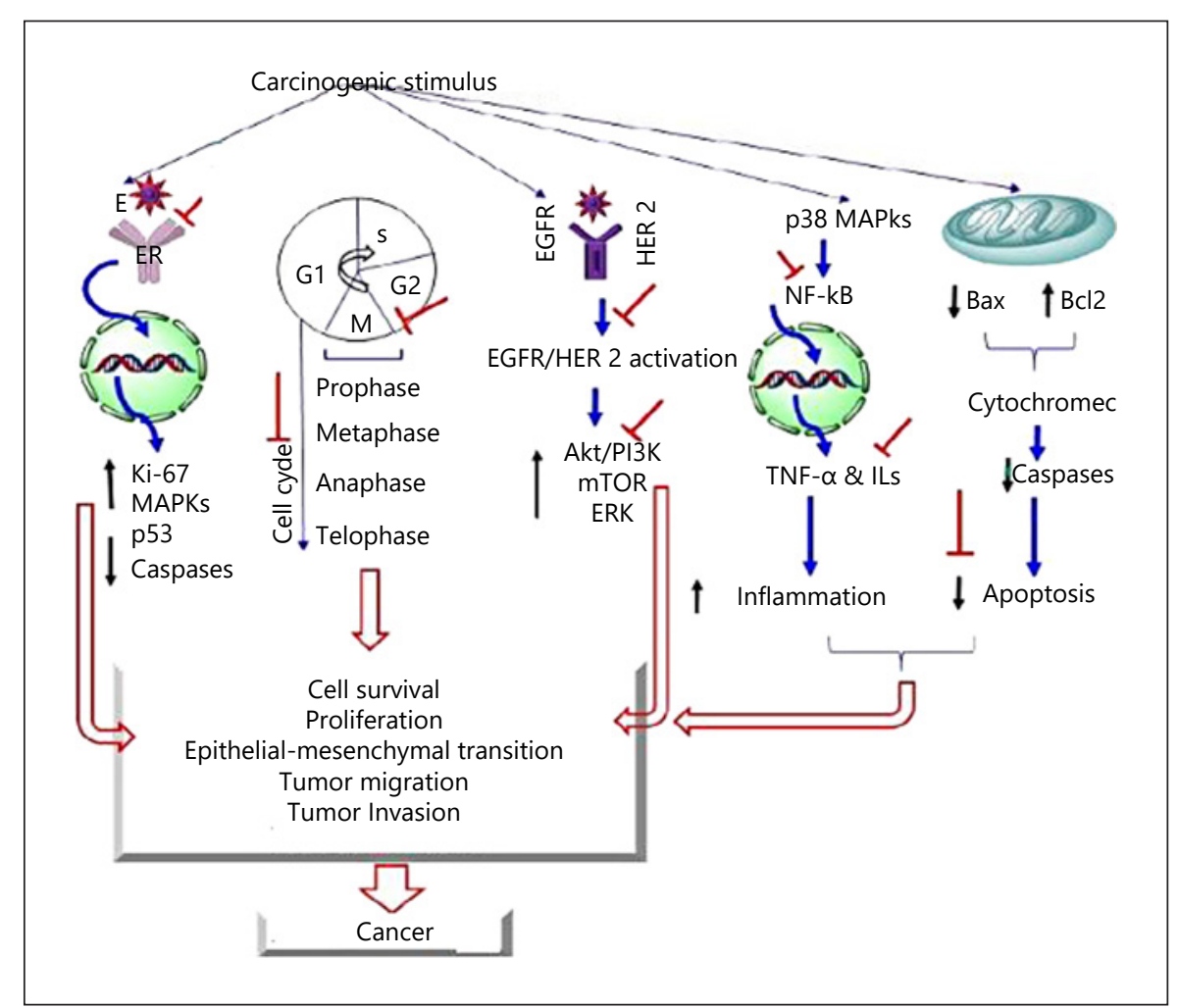

of hepatocellular carcinoma subcutaneous xenografts [90]. All these pieces of evidence from preclinical, clinical, as well as case reports suggest the use of cannabinoids as an analgesic for pain relief, to alleviate the side effects of chemotherapy and that cannabinoids have anticancer property. All these data and findings can be further researched and used for better treatment of cancer. Detailed mechanism of cannabis as potent anticancer drug is shown in Figure 5, and clinical as well as preclinical studies are documented in Tables 3 and 4 for symptomatic relief of cancer chemotherapy and as a novel anticancer agent, respectively.

\section{Chronic Pain and Cannabis}

Pain is defined as an unpleasant sensory and emotional experience that is associated with actual potential tissue damage, and pain is always subjective [106]. Pain can further be classified into acute and chronic. Acute pain is a sensation to a noxious stimulus, and it is temporary. While chronic pain persists, the pain signals keep on stimulating the nervous system for days, weeks, and even years. Chronic pain is usually due to any neurological damage, infection, a result of any ongoing treatment like cancer or maybe due to any other disease like HIV. A sur- vey showed that $>1.5$ billion people in the world suffer from chronic pain, and about $3-4.5 \%$, neuropathic pain [107]. Use of cannabis as a pain reliever has dated back to $2,900 \mathrm{BC}$ in China where it was indicated for rheumatic pain [108] and its concoction with wine was used as anesthesia during surgeries [109]. A phase 1a study showed the reduction of neuropathic pain by $45 \%$ within $20 \mathrm{~min}$ of cannabis inhalation and the pain reached the baseline in $90 \mathrm{~min}$. The only reported adverse effect was tolerable light-headedness which lasted for 15-20 min [110]. A clinical trial showed a significant increase in pain thresholds with reduced pain intensity and a decrease in odynophagia when dronabinol is compared with placebo [111]. A randomized, double-blind, placebo-controlled, crossover design study employing 3 different strengths of inhaled cannabis (placebo, 2.9\%, and delta-9-THC, 6.7\%) found a significant decrease in the pain intensity [112]. In a study with 338 patients with different chronic pain, cannabis flos $19 \%$ for 12 months was given, and pain was found to be significantly decreased from baseline by the end of 12th months with decreases in anxiety and depression [113]. A novel CB2-selective cannabinoid, COR167, was found to inhibit dose-dependent proliferation of blood mononuclear cells and myelin basic protein-reac- 
Table 3. Evidences of use of cannabis component as a symptomatic relief for cancer chemotherapy [80, 82-84, 91-99]

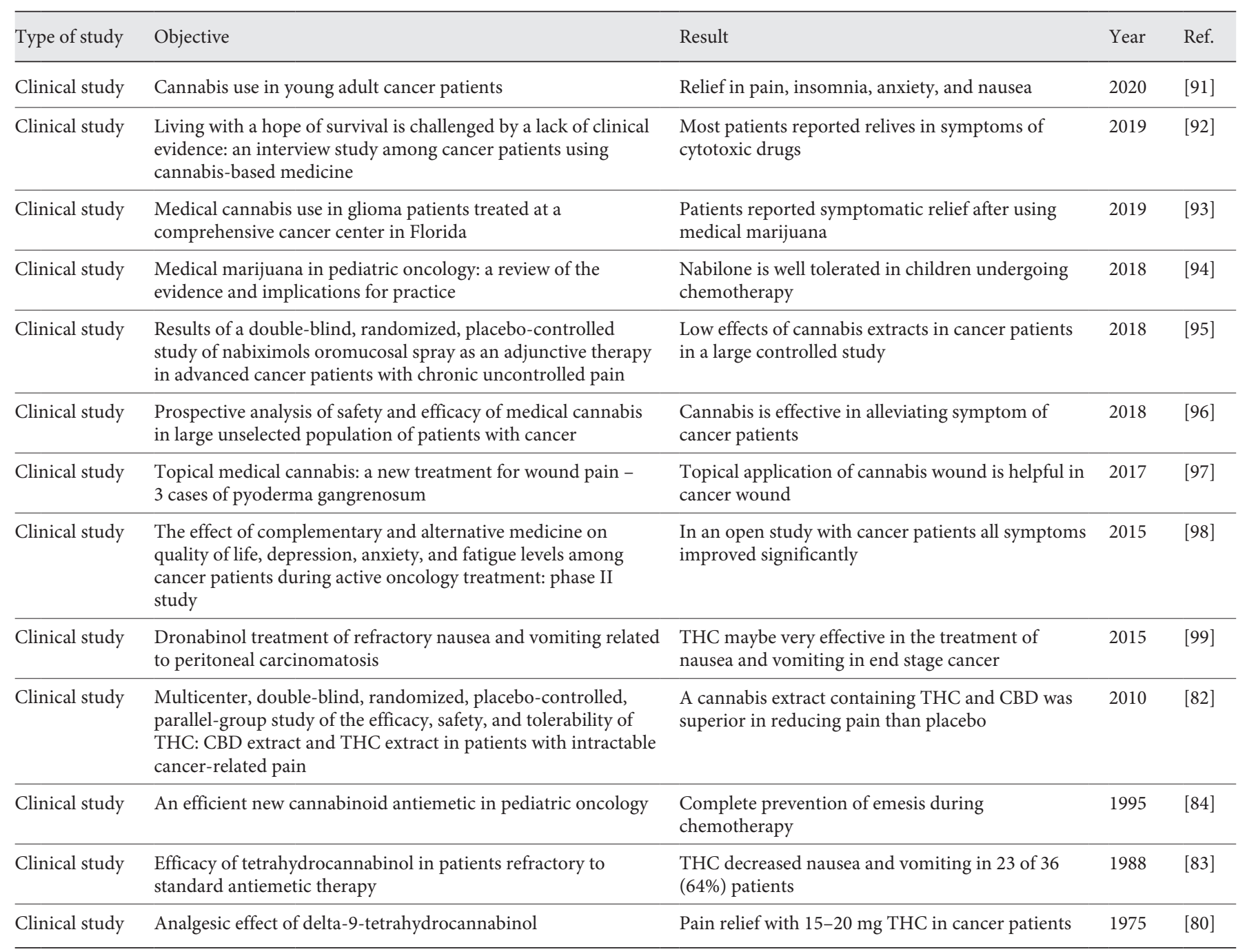

THC, tetrahydrocannabinol; CBD, cannabidiol.

tive T-cell lines in patients with relapsing-remitting multiple sclerosis. Thus, this novel drug was found to have potent immunomodulatory effects and confirms CB2 bindings to be therapeutically significant in neuroinflammation [114]. A research team of Congress of the European Academy of Neurology in Amsterdam investigated the use of cannabis in the prophylaxis of migraine. In the study, 48 patients with chronic migraine pain were selected, no therapeutic effect was seen till $100 \mathrm{mg}$ doses, and at a dose of $200 \mathrm{mg}$ there was a reduction in $55 \%$ of acute pain [59]. In a large multiregional analysis, cannabis for acute myocardial infarction (AMI) was found to be associated with a decrease in the risk of in-hospital mortality, IABP placement, and a shock and an elevation of mechanical ventilation post-AMI [115]. A study for delivery of cannabis extract via buccal route was performed in which 49 patients were taking Troika lozenges. Reduction in pain was initiated within 5-40 min. Adverse effects reported were bad taste, dizziness/unsteadiness, and throat irritation/dry mouth, and none of them were termed to cause serious medical condition and has limited impact on daily function [116]. A study showed that medical cannabis legalization was found to be associated with a reduction of prescription and dosage of schedule III opioids in the US [117]. A retrospective, mirror-image study was performed on the use of medical cannabis for chronic pain. After a treatment of 3 months, medical cannabis improved life, reduced opioid use and pain, and 
Table 4. Evidence of use of cannabis component as a novel anticancer agent [8, 85-90, 100-105]

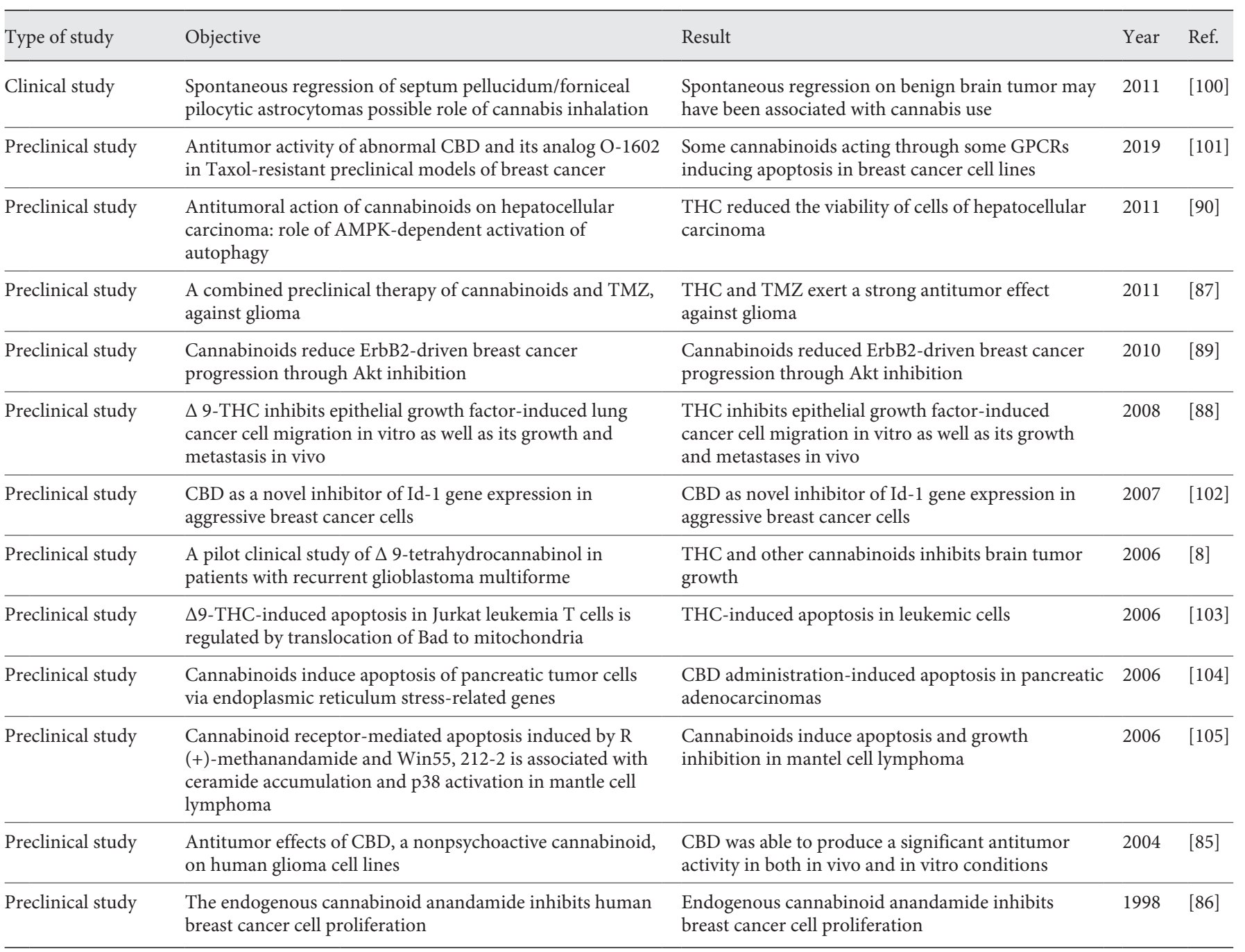

THC, tetrahydrocannabinol; CBD, cannabidiol, TMZ, temozolomide.

saved money [118]. A wide statistical data showed that most of the utilization of medical cannabis was for chronic pain out of which about $88 \%$ of patients were treated for headache and pain due to migraines [119]. Chronic pain is also one of the complications of organ transplants. A study on 7 patients (58-75 years) with a kidney transplant, in Uruguay, was done. The study was to check the analgesic effect of CBD for patients with a kidney transplant. A dose of 50-150 mg was given twice a day for 3 weeks. CBD was found to well tolerated, with no severe side effects, thus did not require discontinuation of the therapy. But a longer follow-up and more patients are required [120]. A double-blind, placebo-controlled study of coadministration of cannabis and an opioid analgesic (oxycodone) was done to check the effect of active cannabis on antinociceptive effect of opioid and to assess the interaction of cannabis with an opioid. Low doses of cannabis and opioid $(2.5 \mathrm{mg})$, when given alone, were not effective in reducing pain, but when given together, pain responses on CPT were significantly reduced. These results correspond to the synergistic effects of cannabis and opioid and can also be utilized to decrease the consumption of opioid analgesics for patients with chronic pain [121]. About 26 patients with fibromyalgia, a chronic pain condition, were treated with medical cannabis for about 11 months. About $50 \%$ of patients showed good tolerance for medical cannabis and stopped taking other analgesics [122] (Table 5). 
Table 5. Evidence of use of cannabis in chronic pain [97, 110-126]

\begin{tabular}{|c|c|c|c|c|}
\hline Type of study & Objective & Result & Year & Ref. \\
\hline Clinical study & $\begin{array}{l}\text { Medical cannabis in patients with chronic pain: effect on pain } \\
\text { relief, pain disability, and psychological aspects: a prospective } \\
\text { nonrandomized single-arm clinical trial }\end{array}$ & $\begin{array}{l}\text { Cannabis tea is effective in treatment of chronic } \\
\text { pain }\end{array}$ & 2018 & [113] \\
\hline Clinical study & $\begin{array}{l}\text { Self-reported effectiveness and safety of Trokie lozenges: a } \\
\text { standardized formulation for the buccal delivery of cannabis } \\
\text { extracts }\end{array}$ & Cannabis lozenges reduces pain & 2018 & [116] \\
\hline Clinical study & $\begin{array}{l}\text { Medical cannabis legalization and opioid prescriptions: } \\
\text { evidence on US Medicaid enrolled during 1993-2014 }\end{array}$ & $\begin{array}{l}\text { Legalization of cannabis for medical use in US is } \\
\text { associated with reduced opioid prescription }\end{array}$ & 2018 & [117] \\
\hline Clinical study & $\begin{array}{l}\text { Preliminary evaluation of the efficacy, safety, and costs } \\
\text { associated with the treatment of chronic pain with medical } \\
\text { cannabis }\end{array}$ & $\begin{array}{l}\text { Cannabis reduces pain and increases quality of life } \\
\text { with patients of chronic pain }\end{array}$ & 2018 & [118] \\
\hline Clinical study & $\begin{array}{l}\text { Chronic pain treatment with CBD in kidney transplant } \\
\text { patients in Uruguay }\end{array}$ & $\begin{array}{l}\text { CBD reduces pain in patients with kidney } \\
\text { transplant }\end{array}$ & 2018 & [120] \\
\hline Clinical study & $\begin{array}{l}\text { Impact of coadministration of oxycodone and smoked } \\
\text { cannabis on analgesia and abuse liability }\end{array}$ & $\begin{array}{l}\text { Cannabis enhances the pain reducing effect when } \\
\text { taken with opioid oxycodone }\end{array}$ & 2018 & [121] \\
\hline Clinical study & $\begin{array}{l}\text { Cannabis use is associated with lower odds of prescription } \\
\text { opioid analgesic use among HIV-infected individuals with } \\
\text { chronic pain }\end{array}$ & $\begin{array}{l}\text { Medical cannabis legislation might reduce the need } \\
\text { of opioid analgesics for HIV-infected individuals } \\
\text { with chronic pain }\end{array}$ & 2018 & [123] \\
\hline Clinical study & Medical cannabis for the treatment of fibromyalgia & $\begin{array}{l}\text { Marijuana has a beneficial effect on patients with } \\
\text { fibromyalgia }\end{array}$ & 2018 & [122] \\
\hline Clinical study & $\begin{array}{l}\text { Effect of medical cannabis on thermal quantitative } \\
\text { measurements of pain in patients with PD }\end{array}$ & $\begin{array}{l}\text { Cannabis use improved pain and movement in } \\
\text { patients with Parkinson's }\end{array}$ & 2017 & [124] \\
\hline Clinical study & $\begin{array}{l}\text { An exploratory human laboratory experiment evaluating } \\
\text { vaporized cannabis in the treatment of neuropathic pain from } \\
\text { spinal cord injury and disease }\end{array}$ & $\begin{array}{l}\text { Inhaled cannabis reduced neuropathic pain in } \\
\text { patients with spinal injury }\end{array}$ & 2016 & [112] \\
\hline Clinical study & $\begin{array}{l}\text { The pharmacokinetics, efficacy, safety, and ease of use of a } \\
\text { novel portable metered-dose cannabis inhaler in patients with } \\
\text { chronic neuropathic pain: a phase la study }\end{array}$ & $\begin{array}{l}\text { A significant reduction in pain after inhalation of } \\
\text { cannabis with neuropathic pain }\end{array}$ & 2014 & [110] \\
\hline Clinical study & $\begin{array}{l}\text { Cannabis induces a clinical response in patients with Crohn's } \\
\text { disease: a prospective placebo-controlled study }\end{array}$ & $\begin{array}{l}\text { Cannabis produced significant clinical benefits in } \\
10 / 11 \text { patients with active Crohn's disease }\end{array}$ & 2013 & [125] \\
\hline Clinical study & $\begin{array}{l}\text { Palmitoylethanolamide in the treatment of chronic pain } \\
\text { caused by different etiopathogenetic }\end{array}$ & $\begin{array}{l}\text { Significant pain relief with PEA in patients with } \\
\text { chronic pain }\end{array}$ & 2012 & [126] \\
\hline Preclinical stud & $\begin{array}{l}\text { Potent immunomodulatory activity of a highly selective } \\
\text { cannabinoid CB2 agonist on immune cells from healthy } \\
\text { subjects and patients with multiple sclerosis }\end{array}$ & $\begin{array}{l}\text { Activation of } \mathrm{CB} 2 \text { receptors counteracts } \\
\text { inflammation of nerve cells }\end{array}$ & 2017 & [114] \\
\hline
\end{tabular}

THC, tetrahydrocannabinol; CBD, cannabidiol; PEA, palmitoylethanolamide; AMI, acute myocardial infarction. 


\section{Unwanted/Adverse Effects of Cannabis}

With the above compiled data and studies over the use and wonders of medical cannabis in various disorders, it becomes equally necessary to look though why this drug got illegal in the first place and what the possible and unwanted side effects that it pose. Major adverse effects of cannabis use were found to be on nervous system and psychiatric health, respiratory system, and cardiovascular system [127]. It is noticed that there is an increased risk of psychiatric disorder on vulnerable population and naïve users post-cannabis use, with anxiety and panic attack in naïve users $[128,129]$. Extended use of cannabis was also associated with behavioral changes such as mania, depression, and mood disturbances. Cannabis dependency and addiction is another major challenge [130, 131]. Cannabis use for a long term was also related with cognitive changes in a dose-related manner that also lead to road accidents. It also leads to long-term brain functional and structural changes [132, 133].

Since the most common way of administration of cannabis is through smoking, it leads to smoking-related adverse effects including airway disease and lung cancer [134]. Smoking itself also poses its cardiovascular impacts such as atherosclerosis. Several reports have described a correlation relationship between cannabis use and AMI, cardiomyopathy, and sudden cardiac death [135]. No drug is safe, same goes for cannabis but that does not mean we should neglect its benefits. More research will lead to fruitful outcomes.

\section{Ethical Considerations versus Medical Necessity}

There has been always a debate emerging among the medical community for the increasing use of alternative medicine, which can also be termed as an unconventional and alternative treatment. A majority of the population is using some sort of alternative treatment, which reflects the change in need and values of today's medication [136]. One such alternative therapy is the use of medical cannabis for both as a treatment or as an aid for patients to withstand the effects of accepted treatments that can cure or help the patient in that condition [137]. According to a survey of 2005, in Americans who were suffering from pain, $20 \%$ rated it to be severe and among the whole population with pain of about $6 \%$ (12 million) smoked cannabis as a remedy [138]. The main issue with the use of cannabis is its classification as schedule I drugs by the Federal Government under the 1970 Uniform
Controlled Substance Act. The DEA rejected the attempts to reassign cannabis to schedule II by saying that "there was no scientific evidence showing that cannabis was better than other approved drugs for any specific medical condition" [139]. Also, DEA refused to reschedule cannabis as it does not have any official determination of safety and efficacy by the FDA. FDA needs controlled, double-blinded clinical trials for rescheduling [140]. Medical cannabis is considered to have great therapeutic potential, but it lacks powerful clinical data. Large clinical trials are very expensive and time consuming, and they are supported by big pharmaceutical companies. Medical cannabis is not under any patent protection so pharmaceutical companies take less incentive toward much needed clinical trials [141]. Furthermore, lack of clinical data compels the physician to prescribe other medications that are expensive and less effective. Forms of cannabis that have been approved for medical use are the following: oral synthetic THC named "dronabinol" (Marinol), approved by FDA in 1985, is a schedule II prescription drug used for nausea and vomiting-related cancer chemotherapy; oral mucosal spray "Sativex" that contains THC and CBD in 1:1 ratio has been approved in the United Kingdom, Canada, and several other countries [142]. Instead of the 2 endorsed cannabis products mentioned above, medical cannabis's most popular way of administration is smoking dried cannabis plant, which consists of THC and CBD in varied concentration with other cannabinoids [143]. Concerns with prescribed approved products of cannabis is that they are very expensive and sometimes pills are difficult to consume for patients with nausea. Smoked cannabis has been argued to be more effective as it is immediately absorbed and reaches the brain effectively and rapidly. In addition, smoked cannabis was found to be cheap. But since dried buds and leaves are smoked, the actual concentration of the active component is difficult to determine; thus, it becomes a drawback. Some studies also showed the potential for toxic compounds in cannabis smoke. Further cannabis can also be accompanied by some microorganisms and fungi which could lead to pulmonary infection, and use of insecticides and pesticides compromise the use of cannabis [139]. In 2017, the FDA approved a pure CBD formulation, Epidiolex, for 2 rare and severe forms of epilepsies. Further, DEA also rescheduled Epidiolex, being a cannabis extract, to schedule V [143]. There are sufficient data that this review contemplates, and many more, to reconsider the scheduling of cannabis so that it can be prescribed by the physicians where conventional therapies are not applicable.
Med Cannabis Cannabinoids 2021;4:43-60 DOI: 10.1159/000515042
Verma/Hoda/Arshad/Iqubal/Siddiqui/ Khan/Haque/Akhtar/Najmi 


\section{Conclusion and Future Prospect}

This study has analyzed and reviewed the historical, botanical, chemical, ethnopharmacological, and legal aspects of $C$. sativa from the first human use to the present medical applications with an analysis of its multiple therapeutic applications for various diseased conditions in the contemporary scientific context. There is an abundance of support for its several medicative uses as well as a possible benefit in various diseased conditions. Extensive pharmacological examination is still needed to better understand the clinical significance and uses of active cannabinoids in the treatment and prevention of chronic diseases. Also, cannabis can be chemically standardized and under prescription can be used. With the majority of the United States currently legalizing medicinal cannabis and/or restricted CBD-only use, physicians need to be educated on the history and correct clinical use of cannabis, as a result of which patients can know more and more about possible treatment utilizing cannabis. Medical cannabis has shown to have clinical efficacy in our past, and in present, data show its therapeutic effects. Extensive research in the field of cannabis can be very fruitful for the medicine world.

\section{Conflict of Interest Statement}

All authors declare no conflict of interest.

\section{Funding sources}

This review did not receive any specific grant from funding agencies in the public, commercial, or not-for-profit sectors.

\section{Author Contributions}

R.V. and F.H. were involved in the study conception/design. M.H. and M.A. were involved in literature search. R.V., F.H., and A.I. were involved in writing the manuscript. A.I., A.N.S., and M.A.K. were involved in drafting and revising the manuscript. S.E.H. and A.K.N. were involved in overall guidance in writing and drafting the manuscript. All authors read and approved the final manuscript.

\section{References}

1 Byrne T, Poling A. Introduction to behavioral pharmacology. New Harbinger Publications; 2000.

2 Ben Amar M, Léonard L. Chapter 16: Cannabis. Les Psychotropes: Pharmacologie et Toxicomanie. Montreal: Les Presses de l'Université de Montréal; 2002. p. 571-627.

3 Piluzza G, Delogu G, Cabras A, Marceddu S, Bullitta S. Differentiation between fiber and drug types of hemp (Cannabis sativa L.) from a collection of wild and domesticated accessions. Genet Resour Crop Evol. 2013;60(8): 2331-42.

4 Andre CM, Hausman JF, Guerriero G. Cannabis sativa: the plant of the thousand and one molecules. Front Plant Sci. 2016;7:19.

5 Smith DE. Review of the American Medical Association Council on Scientific Affairs report on medical marijuana. J Psychoactive Drugs. 1998;30(2):127-36.

6 Glass M, Dragunow M, Faull R. The pattern of neurodegeneration in Huntington's disease: a comparative study of cannabinoid, dopamine, adenosine and GABAA receptor alterations in the human basal ganglia in Huntington's disease. Neuroscience. 2000;97(3): 505-19.

7 McAllister SD, Murase R, Christian RT, Lau $\mathrm{D}$, Zielinski AJ, Allison J, et al. Pathways mediating the effects of cannabidiol on the reduction of breast cancer cell proliferation, in- vasion, and metastasis. Breast Cancer Res Treat. 2011;129(1):37-47.

8 Guzman M, Duarte MJ, Blázquez C, Ravina J, Rosa MC, Galve-Roperh I, et al. A pilot clinical study of $\Delta 9$-tetrahydrocannabinol in patients with recurrent glioblastoma multiforme. Br J Cancer. 2006;95(2):197-203.

9 Volkow ND, Compton WM, Weiss SR. Adverse health effects of marijuana use. $\mathrm{N}$ Engl J Med. 2014;371(9):879-27.

10 Reinarman C, Cohen PD, Kaal HL. The limited relevance of drug policy: cannabis in Amsterdam and in San Francisco. Am J Public Health. 2004;94(5):836-42.

11 Baker D, Pryce G, Giovannoni G, Thompson AJ. The therapeutic potential of cannabis. Lancet Neurol. 2003;2(5):291-8.

12 Devinsky O, Cilio MR, Cross H, Fernandez-Ruiz J, French J, Hill C, et al. Cannabidiol: pharmacology and potential therapeutic role in epilepsy and other neuropsychiatric disorders. Epilepsia. 2014;55(6): 791-802.

13 Mouhamed Y, Vishnyakov A, Qorri B, Sambi M, Frank SMS, Nowierski C, et al. Therapeutic potential of medicinal marijuana: an educational primer for health care professionals. Drug Healthc Patient Saf. 2018;10: 45-66.

14 Devane WA, Hanus L, Breuer A, Pertwee RG, Stevenson LA, Griffin G, et al. Isolation and structure of a brain constituent that binds to the cannabinoid receptor. Science. 1992; 258(5090):1946-9.

15 Maroon J, Bost J. Review of the neurological benefits of phytocannabinoids. Surg Neurol Int. 2018;9:91.

16 Oberbarnscheidt T, Miller NS. Pharmacology of marijuana. J Addict Res Ther. 2017;11:012.

17 Holland J. The pot book: a complete guide to cannabis. Simon and Schuster; 2010.

18 American Cancer Society. Available from: https://www.cancer.org/treatment/treatments-and-side-effects/complementaryand-alternative-medicine/marijuana-andcancer.html\#written_by.

19 Mikuriya TH. Marijuana in medicine: past, present and future. Calif Med. 1969;110(1): 34.

20 Joy J, Mack A. Marijuana as medicine?: the science beyond the controversy. National Academies Press; 2000.

21 Segal B. Perspectives on drug use in the United States. Routledge; 2014.

22 Hosking R, Zajicek J. Therapeutic potential of cannabis in pain medicine. Br J Anaesth. 2008;101(1):59-68.

23 Giancaspro GI, Kim NC, Venema J, de Mars $\mathrm{S}$, Devine J, Celestino C, et al. The advisability and feasibility of developing USP standards for medical cannabis. Pharmacopeial Forum; 2016. 
24 Cameron JM, Dillinger RJ. Narcotic control act. Encyclopedia of drug policy. Thousand oaks, California: SAGE Publications, Inc; 2011. p. 543-5.

25 Ross C. To treat or not to treat?

26 Duthey B. Background paper 6.11: Alzheimer disease and other dementias. A public health approach to innovation. 2013. p. 1-74.

27 Jung YJ, Tweedie D, Scerba MT, Greig NH. Neuroinflammation as a factor of neurodegenerative disease: thalidomide analogs as treatments. Front Cell Dev Biol. 2019;7:313.

28 Liu CS, Chau SA, Ruthirakuhan M, Lanctôt KL, Herrmann N. Cannabinoids for the treatment of agitation and aggression in Alzheimer's disease. CNS Drugs. 2015;29(8):615-23.

29 Shelef A, Barak Y, Berger U, Paleacu D, Tadger S, Plopsky I, et al. Safety and efficacy of medical cannabis oil for behavioral and psychological symptoms of dementia: anopen label, add-on, pilot study. J Alzheimers Dis. 2016;51(1):15-9.

30 Eubanks LM, Rogers CJ, Beuscher AE, Koob GF, Olson AJ, Dickerson TJ, et al. A molecular link between the active component of marijuana and Alzheimer's disease pathology. Mol Pharm. 2006;3(6):773-7.

31 Walther S, Mahlberg R, Eichmann U, Kunz D. Delta-9-tetrahydrocannabinol for nighttime agitation in severe dementia. Psychopharmacology. 2006;185(4):524-8.

32 Volicer L, Stelly M, Morris J, McLaughlin J, Volicer BJ. Effects of dronabinol on anorexia and disturbed behavior in patients with $\mathrm{Alz}$ heimer's disease. Int J Geriatr Psychiatry. 1997;12(9):913-9.

33 Milton NG. Anandamide and noladin ether prevent neurotoxicity of the human amyloid-beta peptide. Neurosci Lett. 2002;332(2):127-30.

34 Woodward MR, Harper DG, Stolyar A, Forester BP, Ellison JM. Dronabinol for the treatment of agitation and aggressive behavior in acutely hospitalized severely demented patients with noncognitive behavioral symptoms. Am J Geriatr Psychiatry. 2014;22(4): 415-9.

35 Hindocha C, Freeman TP, Schafer G, Gardener C, Das RK, Morgan CJ, et al. Acute effects of delta-9-tetrahydrocannabinol, cannabidiol and their combination on facial emotion recognition: a randomised, double-blind, placebo-controlled study in cannabis users. Eur Neuropsychopharmacol. 2015;25(3): 325-34.

36 Passmore MJ. The cannabinoid receptor agonist nabilone for the treatment of dementiarelated agitation. Int J Geriatr Psychiatry. 2008;23(1):116.

37 Haney M, Gunderson EW, Rabkin J, Hart CL, Vosburg SK, Comer SD, et al. Dronabinol and marijuana in HIV-positive marijuana smokers: caloric intake, mood, and sleep. J Acquir Immune Defic Syndr. 2007;45(5):545-54.

38 Russo E, Guy GW. A tale of two cannabinoids: the therapeutic rationale for combining tetrahydrocannabinol and cannabidiol. Med Hypotheses. 2006;66(2):234-46.
39 Schubert D, Kepchia D, Liang Z, Dargusch R, Goldberg J, Maher P. Efficacy of cannabinoids in a pre-clinical drug-screening platform for Alzheimer's disease. Mol Neurobiol. 2019;56(11):7719-30.

40 Esposito G, De Filippis D, Carnuccio R, Izzo AA, Iuvone T. The marijuana component cannabidiol inhibits $\beta$-amyloid-induced tau protein hyperphosphorylation through Wnt/ $\beta$-catenin pathway rescue in PC12 cells. J Mol Med. 2006;84(3):253-8.

41 Van der Stelt M, Mazzola C, Esposito G, Matias I, Petrosino S, De Filippis D, et al. Endocannabinoids and $\beta$-amyloid-induced neurotoxicity in vivo: effect of pharmacological elevation of endocannabinoid levels. Cell Mol Life Sci. 2006;63(12):1410-24.

42 GBD 2016 Neurology Collaborators. Global, regional, and national burden of Parkinson's disease, 1990-2016: a systematic analysis for the Global Burden of Disease Study 2016 Lancet Neurol. 2018;17(11):939-53.

43 Milano W, Capasso A. Neuroprotection by cannabinoids in neurodegenerative diseases. 2018 .

44 Möller T. Neuroinflammation in Huntington's disease. J Neural Transm. 2010;117(8) 1001-8.

45 García-Arencibia M, González S, de Lago E, Ramos JA, Mechoulam R, Fernández-Ruiz J. Evaluation of the neuroprotective effect of cannabinoids in a rat model of Parkinson's disease: importance of antioxidant and cannabinoid receptor-independent properties. Brain Res. 2007;1134:162-70.

46 Frank-Cannon TC, Alto LT, McAlpine FE, Tansey MG. Does neuroinflammation fan the flame in neurodegenerative diseases? Mol Neurodegener. 2009;4(1):47.

47 Longinetti E, Fang F. Epidemiology of amyotrophic lateral sclerosis: an update of recent literature. Curr Opin Neurol. 2019;32(5):771.

48 Shoemaker JL, Seely KA, Reed RL, Crow JP, Prather PL. The CB2 cannabinoid agonist AM-1241 prolongs survival in a transgenic mouse model of amyotrophic lateral sclerosis when initiated at symptom onset. J Neurochem. 2007;101(1):87-98.

49 GBD 2016 Multiple Sclerosis Collaborators Global, regional, and national burden of multiple sclerosis 1990-2016: a systematic analysis for the Global Burden of Disease Study 2016. Lancet Neurol. 2019;18(3):269-85.

50 Wirguin I, Mechoulam R, Breuer A, Schezen E, Weidenfeld J, Brenner T. Suppression of experimental autoimmune encephalomyelitis by cannabinoids. Immunopharmacology. 1994;28(3):209-14

51 Zajicek J, Fox R, Sanders H, Wright D, Vickery J, Nunn AJ, et al. The cannabinoids in MS study-final results form 12 months follow-up. London, England: Multiple Sclerosis; 2004.

52 Beghi E. The Epidemiology of Epilepsy. Neuroepidemiology. 2020;54(2):185-91.

53 Stockings E, Zagic D, Campbell G, Weier M, Hall WD, Nielsen S, et al. Evidence for cannabis and cannabinoids for epilepsy: a sys- tematic review of controlled and observational evidence. J Neurol Neurosurg Psychiatry. 2018;89(7):741-53.

54 Perucca E. Cannabinoids in the treatment of epilepsy: hard evidence at last? J Epilepsy Res. 2017;7(2):61.

55 Cunha JM, Carlini EA, Pereira AE, Ramos OL, Pimentel C, Gagliardi R, et al. Chronic administration of cannabidiol to healthy volunteers and epileptic patients. Pharmacology. 1980;21(3):175-85.

56 Devinsky O, Marsh E, Friedman D, Thiele E, Laux L, Sullivan J, et al. Cannabidiol in patients with treatment-resistant epilepsy: an open-label interventional trial. Lancet Neurol. 2016;15(3):270-8.

57 Tzadok M, Uliel-Siboni S, Linder I, Kramer U, Epstein O, Menascu S, et al. CBD-enriched medical cannabis for intractable pediatric epilepsy: the current Israeli experience. Seizure. 2016;35:41-4.

58 Szaflarski JP, Bebin EM, Cutter G, DeWolfe J, Dure LS, Gaston TE, et al. Cannabidiol improves frequency and severity of seizures and reduces adverse events in an open-label addon prospective study. Epilepsy Behav. 2018 87:131-6.

59 Hausman-Kedem M, Menascu S, Kramer U. Efficacy of CBD-enriched medical cannabis for treatment of refractory epilepsy in children and adolescents: an observational, longitudinal study. Brain Dev. 2018;40(7):544-51.

60 Aguirre-Velázquez CG, Lemus-Roldán K, Kokhreidze J, Darjania L, Titus SW. Efficacy and tolerability of add-on cannabidiol in pediatric patients with drug-resistant epilepsy: an open exploratory interventional study in México. EC Neurol. 2019;12(1):1-11.

61 Kerr A, Walston V, Wong VSS, Kellogg M, Ernst L. Marijuana use among patients with epilepsy at a tertiary care center. Epilepsy Behav. 2019;97:144-8.

62 Neubauer D, Perković Benedik M, Osredkar D. Cannabidiol for treatment of refractory childhood epilepsies: Experience from a single tertiary epilepsy center in Slovenia. Epilepsy Behav. 2018;81:79-85.

63 Devinsky O, Verducci C, Thiele EA, Laux LC, Patel AD, Filloux F, et al. Open-label use of highly purified CBD (Epidiolex ${ }^{\circ}$ ) in patients with CDKL5 deficiency disorder and Aicardi, Dup15q, and Doose syndromes. Epilepsy Behav. 2018;86:131-7.

64 Chen KA, Farrar M, Cardamone M, Gill D, Smith R, Cowell CT, et al. Cannabidiol for treating drug-resistant epilepsy in children the New South Wales experience. Med J Aust. 2018;209(5):217-21.

65 Hess EJ, Moody KA, Geffrey AL, Pollack SF, Skirvin LA, Bruno PL, et al. Cannabidiol as a new treatment for drug-resistant epilepsy in tuberous sclerosis complex. Epilepsia. 2016; 57(10):1617-24.

66 Lorenz R. On the application of cannabis in paediatrics and epileptology. Neuro Endocrinol Lett. 2004;25(1-2):40-4 
67 Warren PP, Bebin EM, Nabors LB, Szaflarski JP. The use of cannabidiol for seizure management in patients with brain tumor-related epilepsy. Neurocase. 2017;23(5-6):1-5.

68 Consroe PF, Wood GC, Buchsbaum H. Anticonvulsant nature of marihuana smoking. JAMA. 1975;234(3):306-7.

$69 \mathrm{Tu}$ L, Lu Z, Ngan MP, Lam FFY, Giuliano C, Lovati E, et al. The brain-penetrating, orally bioavailable, ghrelin receptor agonist HM01 ameliorates motion-induced emesis in Suncus murinus (house musk shrew). Br J Pharmacol. 2020 Apr;177(7):1635-50.

70 Tian L, Qian W, Qian Q, Zhang W, Cai X. Gingerol inhibits cisplatin-induced acute and delayed emesis in rats and minks by regulating the central and peripheral 5-HT, SP, and DA systems. J Nat Med. 2020;74(2): 353-70.

71 Basak S, Gicheru YW, Kumar A, Chakrapani $\mathrm{S}$. Elucidate the binding mechanism of various setrons to 5-HT3AR. Biophys J. 2020 118(3):190a.

72 Wang X, Chen X, Cao L, Zhu L, Zhang Y, Chu $\mathrm{X}$, et al. Mechanism of deoxynivalenol-induced neurotoxicity in weaned piglets is linked to lipid peroxidation, dampened neurotransmitter levels, and interference with calcium signaling. Ecotoxicol Environ Saf. 2020 May; 194:110382.

73 Wooldridge LM, Kangas BD. An assay of drug-induced emesis in the squirrel monkey (Saimiri sciureus). J Med Primatol. 2019; 48(4):236-43.

74 Rock EM, Sullivan MT, Pravato S, Pratt M, Limebeer CL, Parker LA. Effect of combined doses of $\Delta$ 9-tetrahydrocannabinol and cannabidiol or tetrahydrocannabinolic acid and cannabidiolic acid on acute nausea in male Sprague-Dawley rats. Psychopharmacology. 2020 Mar;237(3):901-14

75 Basak S, Gicheru Y, Kapoor A, Mayer ML, Filizola M, Chakrapani S. Molecular mechanism of setron-mediated inhibition of fulllength 5-HT3A receptor. Nat Commun. 2019; 10(1):1-11

76 Anusha S, Saravanan P. A comparative study of Ondansetron and Palonosetron in the control of cisplatin induced emesis. Pharm Innov. 2019;8(1):300-5.

77 Amar MB. Cannabinoids in medicine: a review of their therapeutic potential. J Ethnopharmacol. 2006;105(1-2):1-25.

78 Liano HC, Zakowicz P, Mikołajczak PJAPP. Cannabinoids as antiemetics: a short review. Acta Pol Pharm. 2018;75(5):1063-68.

79 Siegel RL, Miller KD, Jemal A. Cancer statistics, 2020. CA Cancer J Clin. 2020;70(1):7-30 http://dx.doi.org/10.3322/caac.21590.

80 Noyes R Jr, Brunk SF, Baram DA, Canter A. Analgesic effect of delta-9-tetrahydrocannabinol. J Clin Pharmacol. 1975;15(2-3):139-43.

81 Śledziński P, Zeyland J, Słomski R, Nowak A. The current state and future perspectives of cannabinoids in cancer biology. Cancer Med. 2018;7(3):765-75.
82 Johnson JR, Burnell-Nugent M, Lossignol D, Ganae-Motan ED, Potts R, Fallon MT, et al. Multicenter, double-blind, randomized, placebo-controlled, parallel-group study of the efficacy, safety, and tolerability of THC: CBD extract and THC extract in patients with intractable cancer-related pain. J Pain Symptom Manage. 2010;39(2):167-79.

83 McCabe M, Smith FP, Macdonald JS, Woolley PV, Goldberg D, Schein PS. Efficacy of tetrahydrocannabinol in patients refractory to standard antiemetic therapy. Invest New Drugs. 1988;6(3):243-6.

84 Abrahamov A, Abrahamov A, Mechoulam R. An efficient new cannabinoid antiemetic in pediatric oncology. Life Sci. 1995;56(23-24): 2097-102.

85 Massi P, Vaccani A, Ceruti S, Colombo A, Abbracchio MP, Parolaro D. Antitumor effects of cannabidiol, a nonpsychoactive cannabinoid, on human glioma cell lines. J Pharmacol Exp Ther. 2004;308(3):838-45.

86 De Petrocellis L, Melck D, Palmisano A, Bisogno T, Laezza C, Bifulco M, et al. The endogenous cannabinoid anandamide inhibits human breast cancer cell proliferation. Proc Natl Acad Sci U S A. 1998;95(14):8375-80.

87 Torres S, Lorente M, Rodríguez-Fornés F, Hernández-Tiedra S, Salazar M, GarcíaTaboada E, et al. A combined preclinical therapy of cannabinoids and temozolomide against glioma. Mol Cancer Ther. 2011;10(1): 90-103.

88 Preet A, Ganju R, Groopman J. Delta9-Tetrahydrocannabinol inhibits epithelial growth factor-induced lung cancer cell migration in vitro as well as its growth and metastasis in vivo. Oncogene. 2008;27(3):339-46.

89 Caffarel MM, Andradas C, Mira E, Pérez-Gómez E, Cerutti C, Moreno-Bueno G, et al. Cannabinoids reduce ErbB2-driven breast cancer progression through Akt inhibition. Mol Cancer. 2010;9(1):196.

90 Vara D, Salazar M, Olea-Herrero N, Guzmán M, Velasco G, Díaz-Laviada I. Anti-tumoral action of cannabinoids on hepatocellular carcinoma: role of AMPK-dependent activation of autophagy. Cell Death Differ. 2011;18(7): 1099.

91 Donovan KA, Oberoi-Jassal R, Chang YD, Rajasekhara S, Haas MF, Randich AL, et al. Cannabis use in young adult cancer patients. J Adolesc Young Adult Oncol. 2020;9(1):305 .

92 Buchwald D, Brønnum D, Melgaard D, Leutscher PDC. Living with a hope of survival is challenged by a lack of clinical evidence: an interview study among cancer patients using cannabis-based medicine. J Palliat Med. 2020 Aug;23(8):1090-3.

93 Reblin M, Sahebjam S, Peeri NC, Martinez YC, Thompson Z, Egan KM. Medical cannabis use in glioma patients treated at a comprehensive cancer center in Florida. J Palliat Med. 2019;22(10):1202-7.
94 Ananth P, Reed-Weston A, Wolfe J. Medical marijuana in pediatric oncology: a review of the evidence and implications for practice. Pediatr Blood Cancer. 2018;65(2):e26826.

95 Lichtman AH, Lux EA, McQuade R, Rossetti S, Sanchez R, Sun W, et al. Results of a doubleblind, randomized, placebo-controlled study of nabiximols oromucosal spray as an adjunctive therapy in advanced cancer patients with chronic uncontrolled pain. J Pain Symptom Manage. 2018;55(2):179-88.e1.

96 Schleider LB-L, Mechoulam R, Lederman V, Hilou M, Lencovsky O, Betzalel O, et al. Prospective analysis of safety and efficacy of medical cannabis in large unselected population of patients with cancer. Eur J Intern Med. 2018;49:37-43.

97 Maida V, Corban J. Topical medical cannabis: a new treatment for wound pain - three cases of Pyoderma Gangrenosum. J Pain Symptom Manage. 2017;54(5):732-6.

98 Bar-Sela G, Danos S, Visel B, Mashiach T, Mitnik I. The effect of complementary and alternative medicine on quality of life, depression, anxiety, and fatigue levels among cancer patients during active oncology treatment: phase II study. Support Care Cancer. 2015;23(7):1979-85.

99 Hernandez SL, Sheyner I, Stover KT, Stewart JT. Dronabinol treatment of refractory nausea and vomiting related to peritoneal carcinomatosis. Am J Hosp Palliat Care. 2015;32(1):5-7.

100 Foroughi M, Hendson G, Sargent MA, Steinbok P. Spontaneous regression of septum pellucidum/forniceal pilocytic astrocytomas: possible role of Cannabis inhalation. Childs Nerv Syst. 2011;27(4):671-9.

101 Tomko A, O'Leary L, Trask H, Achenbach JC, Hall SR, Goralski KB, et al. Antitumor activity of abnormal cannabidiol and its analog O-1602 in taxol-resistant preclinical models of breast cancer. Front Pharmacol. 2019;10:1124.

102 McAllister SD, Christian RT, Horowitz MP, Garcia A, Desprez PY. Cannabidiol as a novel inhibitor of Id-1 gene expression in aggressive breast cancer cells. Mol Cancer Ther. 2007;6(11):2921-7.

103 Jia W, Hegde VL, Singh NP, Sisco D, Grant S, Nagarkatti M, et al. Delta9-tetrahydrocannabinol-induced apoptosis in Jurkat leukemia $\mathrm{T}$ cells is regulated by translocation of Bad to mitochondria. Mol Cancer Res. 2006; 4(8):549-62.

104 Carracedo A, Gironella M, Lorente M, Garcia S, Guzmán M, Velasco G, et al. Cannabinoids induce apoptosis of pancreatic tumor cells via endoplasmic reticulum stress-related genes. Cancer Res. 2006;66(13):6748-55.

105 Gustafsson K, Christensson B, Sander B, Flygare J. Cannabinoid receptor-mediated apoptosis induced by $\mathrm{R}(+)$-methanandamide and Win55,212-2 is associated with ceramide accumulation and p38 activation in mantle cell lymphoma. Mol Pharmacol. 2006;70(5):1612-20. 
106 Gebhart G. Pathobiology of visceral pain: molecular mechanisms and therapeutic implications. IV. Visceral afferent contributions to the pathobiology of visceral pain. Am J Physiol Gastrointest Liver Physiol. 2000;278(1):G834-8.

107 Global Industry Analysts. Global glyphosate market to reach 1.35 million metric tons by 2017, according to a new report by Global Industry Analysts, Inc. 2011 Oct 10.

108 Touw M. The religious and medicinal uses of Cannabis in China, India and Tibet. J Psychoactive Drugs. 1981;13(1):23-34.

$109 \mathrm{Li} \mathrm{H}-\mathrm{L}$. The origin and use of Cannabis in eastern Asia linguistic-cultural implications. Econ Bot. 1974;28(3):293-301.

110 Eisenberg E, Ogintz M, Almog S. The pharmacokinetics, efficacy, safety, and ease of use of a novel portable metered-dose cannabis inhaler in patients with chronic neuropathic pain: a phase 1a study. J Pain Palliat Care Pharmacother. 2014;28(3):21625 .

111 Malik Z, Bayman L, Valestin J, Rizvi-Toner A, Hashmi S, Schey R. Dronabinol increases pain threshold in patients with functional chest pain: a pilot double-blind placebocontrolled trial. Dis Esophagus. 2017;30(2): 1.

112 Wilsey B, Marcotte TD, Deutsch R, Zhao H, Prasad H, Phan A. An exploratory human laboratory experiment evaluating vaporized cannabis in the treatment of neuropathic pain from spinal cord injury and disease. J Pain. 2016;17(9):982-1000.

113 Poli P, Crestani F, Salvadori C, Valenti I, Sannino C. Medical cannabis in patients with chronic pain: effect on pain relief, pain disability, and psychological aspects. A prospective non randomized single arm clinical trial. Clin Ter. 2018 May-Jun;169(3):e1027.

114 Annunziata P, Cioni C, Mugnaini C, Corelli F. Potent immunomodulatory activity of a highly selective cannabinoid CB2 agonist on immune cells from healthy subjects and patients with multiple sclerosis. J Neuroimmunol. 2017;303:66-74.

115 Johnson-Sasso CP, Tompkins C, Kao DP, Walker LA. Marijuana use and short-term outcomes in patients hospitalized for acute myocardial infarction. PLoS One. 2018; 13(7): 0199705

116 Crowley K, de Vries ST, Moreno-Sanz G Self-reported effectiveness and safety of Trokie $^{\varnothing}$ lozenges: a standardized formulation for the buccal delivery of cannabis extracts. Front Neurosci. 2018;12:564.

117 Liang D, Bao Y, Wallace M, Grant I, Shi Y Medical cannabis legalization and opioid prescriptions: evidence on US Medicaid enrollees during 1993-2014. Addiction. 2018; 113(11):2060-70

118 Bellnier T, Brown GW, Ortega TR. Preliminary evaluation of the efficacy, safety, and costs associated with the treatment of chronic pain with medical cannabis. Mental Health Clinician. 2018;8(3):110-5.

119 Baron EP, Lucas P, Eades J, Hogue O. Patterns of medicinal cannabis use, strain analysis, and substitution effect among patients with migraine, headache, arthritis, and chronic pain in a medicinal cannabis cohort. J Headache Pain. 2018;19(1):37.

120 Cuñetti L, Manzo L, Peyraube R, Arnaiz J, Curi L, Orihuela S. Chronic pain treatment with cannabidiol in kidney transplant patients in Uruguay. Transplant Proc. 2018 Mar;50(2):461-4

121 Cooper ZD, Bedi G, Ramesh D, Balter R, Comer SD, Haney M. Impact of co-administration of oxycodone and smoked cannabis on analgesia and abuse liability. Neuropsychopharmacology. 2018;43(10):204655.

122 Habib G, Artul S. Medical cannabis for the treatment of fibromyalgia. J Clin Rheumatol. 2018;24(5):255-8.

123 Sohler NL, Starrels JL, Khalid L, Bachhuber MA, Arnsten JH, Nahvi S, et al. Cannabis use is associated with lower odds of prescription opioid analgesic use among HIV infected individuals with chronic pain Subst Use Misuse. 2018;53(10):1602-7.

124 Shohet A, Khlebtovsky A, Roizen N, Roditi Y, Djaldetti R. Effect of medical cannabis on thermal quantitative measurements of pain in patients with Parkinson's disease. Eur J Pain. 2017;21(3):486-93.

125 Naftali T, Bar-Lev Schleider L, Dotan I, Lansky EP, Sklerovsky Benjaminov F, Konikoff FM. Cannabis induces a clinical response in patients with Crohn's disease: a prospective placebo-controlled study. Clin Gastroenterol Hepatol. 2013;11(10):1276-80.e1.

126 Gatti A, Lazzari M, Gianfelice V, Di Paolo A, Sabato E, Sabato AF. Palmitoylethanolamide in the treatment of chronic pain caused by different etiopathogenesis. Pain Med. 2012;13(9):1121-30.

127 Cohen K, Weizman A, Weinstein A. Positive and negative effects of cannabis and cannabinoids on health. Clin Pharmacol Ther. 2019;105(5):1139-47.

128 D’Souza DC, Perry E, MacDougall L, Ammerman Y, Cooper T, Wu YT, et al. The psychotomimetic effects of intravenous delta-9-tetrahydrocannabinol in healthy individuals: implications for psychosis. Neuropsychopharmacology. 2004;29(8):1558-72.
129 Di Forti M, Marconi A, Carra E, Fraietta S, Trotta A, Bonomo M, et al. Proportion of patients in south London with first-episode psychosis attributable to use of high potency cannabis: a case-control study. Lancet Psychiatry. 2015;2(3):233-8

130 Gibbs M, Winsper C, Marwaha S, Gilbert E, Broome M, Singh SP. Cannabis use and mania symptoms: a systematic review and meta-analysis. J Affect Disord. 2015;171:39-47.

131 Horwood LJ, Fergusson DM, Coffey C, Patton GC, Tait R, Smart D, et al. Cannabis and depression: an integrative data analysis of four Australasian cohorts. Drug Alcohol Depend. 2012;126(3):369-78.

132 Van Os J, Bak M, Hanssen M, Bijl RV, de Graaf R, Verdoux H. Cannabis use and psychosis: a longitudinal population-based study. Am J Epidemiol. 2002;156(4):31927.

133 Lorenzetti V, Solowij N, Yücel M. The role of cannabinoids in neuroanatomic alterations in cannabis users. Biol Psychiatry. 2016;79(7):e17-31

134 Tashkin DP, Simmons MS, Tseng CH. Impact of changes in regular use of marijuana and/or tobacco on chronic bronchitis. COPD. 2012;9(4):367-74

135 Tait RJ, Caldicott D, Mountain D, Hill SL, Lenton S. A systematic review of adverse events arising from the use of synthetic cannabinoids and their associated treatment. Clin Toxicol). 2016;54(1):1-13.

136 Jonas WB. Alternative medicine: learning from the past, examining the present, advancing to the future. JAMA. 1998;280(18): 1616-8.

137 Annas GJ. Reefer madness-the federal response to California's medical-marijuana law. New Engl J Med. 1997;337:435-9.

138 Russo EB. Cannabinoids in the management of difficult to treat pain. Ther Clin Risk Manag. 2008;4(1):245.

139 Clark PA. The ethics of medical marijuana: Government restrictions vs. medical necessity. J Public Health Policy. 2000;21(1):4060.

140 McPartland JM, Pruitt PL. Medical marijuana and its use by the immunocompromised. Altern Ther Health Med. 1997;3(3):39-45.

141 Todd $\mathrm{T}$. The benefits of marijuana legalization and regulation. Berkeley J Crim L. 2018; 23:99.

142 Perez J, Ribera MV. Managing neuropathic pain with Sativex ${ }^{\oplus}$ : a review of its pros and cons. Expert Opin Pharmacother. 2008; 9(7):1189-95.

143 Wise J. FDA approves its first cannabis based medicine. BMJ. 2018 Jun 27;361: k2827. 